NBER WORKING PAPER SERIES

\title{
VOCATIONAL AND CAREER TECH EDUCATION IN AMERICAN HIGH SCHOOLS: THE VALUE OF DEPTH OVER BREADTH
}

\author{
Daniel Kreisman \\ Kevin Stange \\ Working Paper 23851 \\ http://www.nber.org/papers/w23851 \\ NATIONAL BUREAU OF ECONOMIC RESEARCH \\ 1050 Massachusetts Avenue \\ Cambridge, MA 02138 \\ September 2017
}

We thank the Institute for Research on Poverty's Emerging Scholars Grants program and the Smith Richardson Foundation for funding and support, and to Daniela Morar and Julian Hsu for excellent research assistance. We also thank seminar participants at the University of Michigan, the University of Tennessee and Kansas State University for helpful comments. The views expressed herein are those of the authors and do not necessarily reflect the views of the National Bureau of Economic Research.

NBER working papers are circulated for discussion and comment purposes. They have not been peer-reviewed or been subject to the review by the NBER Board of Directors that accompanies official NBER publications.

(C) 2017 by Daniel Kreisman and Kevin Stange. All rights reserved. Short sections of text, not to exceed two paragraphs, may be quoted without explicit permission provided that full credit, including (๑) notice, is given to the source. 
Vocational and Career Tech Education in American High Schools: The Value of Depth Over

Breadth

Daniel Kreisman and Kevin Stange

NBER Working Paper No. 23851

September 2017

JEL No. I21,J24

\begin{abstract}
Vocational education is a large part of the high school curriculum, yet we have little understanding of what drives vocational enrollment or whether these courses help or harm early careers. To address this we develop a framework for curriculum choice, taking into account ability and preferences for academic and vocational work. We test model predictions using detailed transcript and earnings information from the NLSY97. Our results are two-fold. First, students positively sort into vocational courses, suggesting the belief that low ability students are funneled into vocational coursework is unlikely true. Second, we find higher earnings among students taking more upper-level vocational courses - a nearly $2 \%$ wage premium for each additional year, yet we find no gain from introductory vocational courses. These results suggest (a) policies limiting students' ability to take vocational courses may not be welfare enhancing, and (b) the benefits of vocational coursework accrue to those who focus on depth over breadth.
\end{abstract}

\author{
Daniel Kreisman \\ Department of Economics \\ Andrew Young School of Policy Studies \\ Georgia State University \\ P.O. Box 3992 \\ Atlanta, GA 30302-3992 \\ dkreisman@gsu.edu \\ Kevin Stange \\ Gerald R. Ford School of Public Policy \\ University of Michigan \\ 5236 Weill Hall \\ 735 South State Street \\ Ann Arbor, MI 48109 \\ and NBER \\ kstange@umich.edu
}




\section{Introduction}

Since the publication of A Nation At Risk in 1983, policy-makers and politicians have turned attention to a perceived educational decline of American youth. Stagnant high school graduation rates, declining test scores, and signs that many college entrants are ill prepared for college and the workforce have all contributed to this perception. Many states have responded to this alarm by increasing high school graduation requirements, typically specifying a minimum number of years spent studying academic subjects such as English, mathematics, science, and social studies.

These reforms have had the intended effects on curriculum: American high school graduates are completing more courses in these academic subjects, and more advanced academic coursework than they were three decades ago. However, much of these gains have come at the expense of vocational oriented, or career and technical, education (CTE). ${ }^{1}$ In fact, between 1990 and 2009 the number of vocational credits earned by high school graduates dropped by $14 \%$, or roughly two-thirds of a year of vocational education, continuing a trend from the previous decade (Hudson, 2013). This drop, shown in Figure 1, coincides with a $32 \%$ decline in real federal funding under the Perkins Act since 1985 (the largest funding source for vocational programs), despite large increases in federal funding for secondary school more generally. ${ }^{2}$ This trend toward academic coursework has been praised by many who argue that vocational education in high school prepares students for "dead end" jobs and leaves them ill-prepared for college. An opposing camp points to (perceived) shortages in skilled professions, noting that not all students are college-bound and that for these students vocational training may be the difference between high and low paying jobs. They further note that young people in other OECD countries enter the labor market with far more occupationally

\footnotetext{
${ }^{1}$ The field has moved towards the use of the the term "career and technical education", including in the title of the 2006 Perkins Act reauthorization, to differentiate current career-focused education from past vocational education. Throughout we use the terms "vocational education," "career-tech," and "CTE" interchangeably.

${ }^{2}$ US DOE, 2014.
} 
relevant skills and credentials than they do in the U.S., alleging a much smoother transition into adulthood (Rosenbaum, 2001; Symonds, 2011). These claims are not unfounded. Yet, while researchers can point to evidence of a positive relationship between high school vocational course-taking and later outcomes in the international context (Eichhorts et al., 2015; Zimmerman, et al., 2013), very little recent evidence exists in the U.S. context on either side of the debate. In the following we evaluate these claims by assessing the relationship between vocational education in high school, postsecondary attainment and labor market outcomes using a nationally representative sample of U.S. high school students.

[Figure 1]

In our analysis we draw particular attention to factors that predict vocational coursetaking (choices) and the ensuing impacts (outcomes) on college-going and wages. While the few existing studies have found largely positive impacts of vocational course-taking on earnings (Mane, 1999; Bishop \& Mane, 2004, 2005; Meer, 2007), and mixed evidence on high school graduation and college attendance (Maxwell \& Rubin, 2002; Agodini \& Deke, 2004; Neumark \& Rothstein, 2005, 2006; Cellini, 2006), these and others frame vocational coursetaking as a "track" rather than as a marginal curriculum choice as is traditionally done for other subjects, particularly mathematics. Our analysis thus departs from previous work in several regards. First, we develop a framework for curriculum choice in which students make curriculum and college decisions in response to information about ability and preferences for vocational or academic (course)work. Second, we treat vocational course-taking as marginal decision, rather than a choice of "track", which our empirical evidence suggests is appropriate. Third, we observe students in the labor market to evaluate wage gains from additional vocational courses, allowing for differential returns to general versus specialized vocational coursework. Lastly, we observe how returns vary across vocational fields, and by local labor market characteristics.

We use detailed longitudinal transcript and labor market information for respondents in the NSLY97 to examine these questions, exploiting a rich set of background and ability mea- 
sures available to us. We ultimately find that more vocational courses are associated with higher wages, on the order of 1.8-2.0 percent for each year of specialized vocational coursework, and lower incidence of "idleness" (neither working nor in school) after high school. But, these returns are not uniformly distributed across all vocational course-takers. Separating vocational coursework into "higher" and "lower" levels, corresponding to introductory courses and specialized coursework within a vocational discipline, we find that wage gains are driven entirely by upper-level courses, largely in technical fields and among non-college graduates. We estimate no wage gain to an additional introductory level vocational course. In addition, we find little evidence that vocational coursework decreases the likelihood of college graduation, though we find suggestive evidence that it may deter the marginal college-goer, implying that those pulled out of college might have been the least likely to graduate. Analogously, we also find that while the labor market value of non-vocational coursework is entirely explained by increased college-going and graduation, the value of vocational coursework is unaffected by accounting for college enrollment and completion.

Our results corroborate a model of positive selection into high school course of study. Exploiting variation in graduation requirements to instrument for curriculum choice supports this, showing that gains accrue to students who select into vocational coursework, but that students induced into additional courses see no advantage. The policy implications from these findings are straightforward and two-fold. First, students appear to positively sort into vocational courses suggesting the commonly held belief that low ability or low effort students are funneled into vocational coursework is unlikely to be true (a negative selection story). Thus, policies that limit students' ability to take these courses, for example increasing requirements in other disciplines, may not be welfare enhancing. Second, the benefits of vocational coursework accrue to students who specialize, rather than those who take multiple vocational courses in several areas. Hence, CTE programs should allow for depth in any topic offered. Recent trends towards more specialized CTE concentrations or "pathways" (away from general, non-specialized coursework) may therefore be smart policy. 


\section{Background and Framing}

\subsection{Prior work}

Compared with an expansive literature on the returns to additional years of schooling, there is relatively little evidence on the labor market consequences of high school curriculum in the U.S., and even less work on effects of vocational course-taking in particular. The value of vocational education has also been subject to debate in both developing and transitional economies, with prior research finding minimal to positive effects on education and labor market outcomes (Malamud \& Pop-Eleches, 2010; Attanasio, et al., 2011; Eichhorst, et al. 2015). Those studies that evaluate the impact of vocational course-work largely treat vocational curriculum as a binary choice - students are either on the "academic" or "vocational" track - as opposed to evaluating the impact of an additional course as one might in, say, mathematics or English. For example, Meer (2007) examines the relationship between "track" (academic, general, business vocational, technical vocational) and earnings later in life. He finds evidence of comparative advantage: students currently on a "technical" vocational track would not gain from switching to an "academic" track, nor would those currently on the academic track benefit from more vocational education.

This is not the only study to find benefits to vocational coursework. Pooling data across several cohorts, Mane (1999) finds positive labor market payoffs to vocational coursework and demonstrates that these were increasing through the 1980s, particularly for non-college bound students. In newer research, Dougherty (forthcoming) finds large high school graduation effects from students who are just accepted into career academies in Massachusetts compared with those who just miss the cutoff. Analyses using older cohorts have gener-

ally supported the same conclusions (Gustman \& Steinmeier, 1982; Kang \& Bishop, 1989; Bishop \& Mane, 2005). Yet, selection is an issue in evaluating vocational programs and none of these studies use exogenous variation. Using the same data we do, Zietz \& Joshi 
(2005) point out that participation in the vocational track is much more common among disadvantaged students. Recent studies commissioned by the US Department of Education as part of the national assessment of CTE required by Perkins reauthorization used various quasi-experimental methods applied to longitudinal student-level data from two locales (Philadelphia and San Diego), one state (Florida), and one nationally-representative high school cohort (ELS 2002). These studies found mixed evidence of the effects of CTE on secondary, postsecondary, and labor market outcomes (US DOE, 2014; Furstenberg Jr. \& Neumark, 2005). In more recent work, Hanushek, et al. (2016) find initial benefits of vocational training, yet they find these come at a cost of adaptability to changing labor market conditions in later life. Taken as a whole, evidence on the effects of vocational coursework is mixed.

A related body of work explores the effect of participation in "School-to-Work" (STW) programs on education and labor market outcomes using early waves of the NLSY97. This literature has evolved mostly in parallel to the above mentioned literature on high school curriculum and vocational education, which is surprising since School-to-Work programs can be seen as a close substitute, in purpose if not structure, to traditional vocational coursework. The results, again, are mixed. Neumark \& Joyce (2001) find few effects of STW participation on "behavior associated with future college attendance", but find positive effects on students' beliefs that they will complete high school and their beliefs about future labor market participation. Neumark \& Rothstein $(2005,2006)$ find some positive benefits on college attendance and the likelihood of later employment although these accrue largely for males and in programs with direct links to the labor market (internships and cooperative education); they in fact find some negative effects from tech-prep. ${ }^{3}$ Cellini (2006) uses a sibling fixed effects model and focuses only on tech-prep, finding that participants are more likely to complete high school and attend a two-year college, resulting in a higher overall attainment, but that this comes at a cost of a decline in 4-year college attendance.

\footnotetext{
${ }^{3}$ Tech-prep is a designation of School-To-Work programs focused on workforce training in applied fields such as manufacturing, automotive or construction.
} 
A separate literature has evolved which estimates the consequences of high school curriculum choice, much of which is summarized in Altonji, Blom, \& Meghir (2012). In the U.S. much of this work focuses specifically on mathematics course-taking (Altonji 1995; Levine \& Zimmerman, 1995; Rose \& Betts, 2004; Goodman, 2012; Joensen \& Nielsen, 2009), generally finding that more math has a positive association with earnings. Importantly, unlike the literature on returns to taking a particular "track", this literature treats each course as a decision on a continuum, allowing for marginal as opposed to discrete changes in curriculum choice. We build on this work by explicitly examining both high school curriculum choice and outcomes, with a focus on the number of vocational courses students choose to take.

Blending these two literatures, we treat curriculum as a continuum, a decision informed by Figure 2, which depicts the cumulative distribution of the total number of vocational credits taken by respondents in the National Longitudinal Survey of Youth (1997). Figure 2 suggests (i) that vocational courses account for a non-trivial share of high school coursework - roughly 50 percent of students take 4 years worth of vocational coursework, (ii) that an overwhelming majority of students take at least one vocational course in high school, and (iii) that the distribution is smooth, rather than bimodal, as strong "tracking" would imply. We frame the decision to take vocational course as the result of students learning about their comparative advantage and preferences for vocational or academic (course-)work. In response to baseline expectations and received signals about "fit", students rationally decide whether to pursue a more vocational or academic focused curriculum as high school progresses. Students consider both human capital and informational consequences of their choices, as curriculum also provides information about labor market prospects. While several studies of college persistence and major choice have this dynamic flavor (e.g., Arcidiacono, 2004; Stinebrickner \& Stinebrickner, 2011; Stange, 2012), this has been mostly absent from studies of high school curricula. Related, Malamud (2011) finds that exposure to a broader curriculum reduces job switches later in life (interpreted as "mistakes") by improving match quality at the expense of greater specialization. 
[Figure 2]

\subsection{Theoretical Framework}

To frame our empirical analysis, we consider a stylized model of high school curriculum choice, college enrollment, college completion and labor market entry in which students are forward-looking but face uncertainty about their ability similar to Altonji (1995). We assume students are endowed with ability along two dimensions: academic ability $\alpha_{a}$ and vocational ability $\alpha_{v}$. These endowed abilities are augmented by investments in human capital through curriculum choices manifested in the number of academic and vocational courses students take, $A$ and $V$ respectively. We define human capital stock $K$ at time $t$ as a function of ability and curriculum choice, including college:

$$
K_{t}=k_{a, t}\left(\alpha_{a}, A\right), k_{v, t}\left(\alpha_{v}, V\right)
$$

We assume academic ability $\left(\alpha_{a}\right)$ influences performance in academic subjects in high school and in college, and the likelihood of college graduation, while vocational ability $\left(\alpha_{v}\right)$ influences performance in vocational subjects in high school. Allowing for effects of $\alpha_{j}$ on $k_{\sim j, t}$ or on performance in opposite type courses does not change inference, rather it simply suggests that there are complementarities. Neither component of ability is known at the start of high school, though students have prior beliefs, which depend on fixed characteristics $(X)$ we assume are observed by the econometrician. Students learn about $\alpha_{a}$ and $\alpha_{v}$ via performance in academic and vocational subjects respectively manifested in grades conditional on covariates - i.e. grades relative to what would be expected. For instance, students that perform better in academic courses than their baseline characteristics would predict will revise their belief about $\alpha_{a}$ upward. These posterior beliefs then influence students' subsequent decisions about high school curriculum, graduation and college enrollment. The likelihood of four-year college graduation, $\operatorname{pr}($ college $)=g\left(k_{a}, X\right)$, then depends on academic capital, which is a function 
of high school curriculum and ability, and on covariates observable to the econometrician. We assume graduation from a two-year institution can depend on $k_{v}$ as well.

We define the labor market as having multiple sectors, delineated by highest degree completed, which define the distribution from which workers draw wages. Both ability components impact productivity in the labor market, though the importance of each may vary by sector; that is, $k_{a}$ may be more valuable in the college-educated labor market while $k_{v}$ may be more valuable in the non-four-year college educated sector. Thus, (log) wage at time $t$ in sector $j$ depends on accumulated skills that are a function of ability and education $k_{a, t}\left(\alpha_{a}, A\right)$ and $k_{v, t}\left(\alpha_{v}, V\right)$ - plus covariates such as work experience, year and local labor market conditions.

$$
\begin{aligned}
& w_{t}^{j}=f\left(k_{a, t}, k_{v, t}, X\right) \\
& \quad \text { for } j=\{\text { drop out, H.S., 2-yr college, 4-yr college }\} .
\end{aligned}
$$

During high school students receive utility which depends on curriculum (i.e. mix of academic and vocational coursework) and expected performance in the chosen curriculum. Utility during college depends on expected performance in college, covariates, and high school curriculum. Utility in the labor market depends only on log wages here, but might also include a hedonic preference for job type. Students sequentially choose high school curriculum (or dropout) and then whether or not to enroll in two- or four-year college to maximize the present discounted value of lifetime utility. Before each of these decisions, students update their beliefs about own academic and vocational ability.

The model delineates several tradeoffs in the choice of curriculum. First, high school vocational courses could have lower psychic costs than academic ones for students with high $\alpha_{v}$ (low $\alpha_{a}$ ). Second, they could be productivity-enhancing for students that enter the non-(four-year) college job sector. Third, they could provide students with the opportunity to acquire more information about $\alpha_{v}$, which should enable better decisions about college 
enrollment. Productivity in the non-college sector is an important factor in college enrollment decisions, yet many students may lack individual-specific information about this parameter. Exposure to vocational curriculum may be one way to acquire it.

However, vocational coursework could have drawbacks. If the vocational track is less rigorous, it may leave students ill-prepared for college and reduce the likelihood of graduating college among those that enroll. Additionally, vocational concentrators may experience reduced productivity in the college job sector if academic coursework is more productivity-enhancing than vocational among college graduates. Similarly, reduced collegiate performance may also mean that vocational students have a greater psychic cost of going to college than those on the academic track. Lastly, students on the vocational track will necessarily have less information about $\alpha_{a}$ than those that pursue the academic track. This may cause some who would benefit from enrolling in college to forego higher education (and the subsequent returns).

One implication of the model is that providing the option of studying a vocational curriculum has ambiguous effects on many outcomes overall since the effects are likely to be quite heterogeneous. For students with diffuse priors about their abilities, exposure to vocational coursework could either increase or decrease college enrollment depending on whether estimates of $\alpha_{a}$ and $\alpha_{v}$ are revised upwards or downward. Regardless, the additional option should improve welfare even among those who reduce college enrollment rates because it reduces dropout (i.e. bad matches between students and college).

\subsection{Predictions}

We use this framework to derive predictions for our empirical analysis. Above we describe a story about selection, akin to a Roy-type model. Those students who expect higher returns to vocational coursework will be more likely to enroll in those courses. While this may seem obvious, it clarifies an important yet subtle point: studying curriculum choice does not lend itself well to the randomization framework often employed in educational research. Why? Imagine that we randomly assigned some students to vocational coursework and others not 
and did not allow for defiers, what should we expect? We should expect all compliers to be worse off if they had good information ex ante. Those who would have chosen a vocational track in the absence of the experiment (the always-takers) will see positive returns while those who would have otherwise enrolled in college-prep coursework (the compliers) should see negative returns compared with their counterfactual. In this framework, only those who would have made ex ante poor decisions would be made better off by having someone else (the experimenter) choose differently for them. The problem with this hypothetical experiment is that the econometrician does not know what students would have taken in the absence of random assignment. This would be akin to randomly or experimentally assigning college majors.

This thought experiment helps frame our predictions. These predictions result from two elements of our theoretical framework. First, that the value of college-prep coursework accrues though an increased likelihood of college attendance and graduation. Thus, we should observe that earnings gains from non-vocational coursework should be largely if not entirely explained by college-going. Second, that students have reasonably good information and self-select. Thus, we should observe that experimental variation in vocational course-taking, which we induce through graduation requirements as a supplemental test, should have zero effect on earnings. In our empirical exercises below we find that each of these predictions bears out.

\section{Data Sources and Sample}

\subsection{The NLSY97 and Transcripts}

We examine schooling and labor market activity for respondents in the National Longitudinal Study of Youth 1997 cohort (NLSY97). This data includes 8,984 individuals who were ages 12 to 18 when they were first interviewed in 1997. The survey is representative of all American youth at that time period and respondents have been followed annually with in-

formation on educational attainment, labor market experience and family formation. High 
school transcripts were collected from respondents' high schools in two waves by the National Opinion Research Center (NORC), who administers the NLSY. The first was conducted in 1999-2000 for 1,391 respondents who were no longer enrolled in high school at that time. Transcripts for 4,618 additional respondents were collected in 2004. In total, transcript data were collected for 6,009 respondents.

NORC used course catalogs to categorize all transcript course titles to a common scheme according to the Secondary School Taxonomy (SST-R). To create uniformity in credit taking, courses are converted into "Carnegie credits" where one Carnegie credit is defined as a course that meets every day for one period for an entire school year. Similarly, grades for each course were converted by NORC into a common (0-4) metric. ${ }^{4}$

Importantly, this careful course coding allows us to disaggregate courses into "low" and "high" level courses. For vocational courses, lower level courses are those classified as "1st course" on transcripts. Upper level courses include courses beyond the introductory level, including: "2nd or later courses", "Specialty course", or "Co-op/Work Experience" in the transcripts. This disaggregation allows us to analyze the benefits of breadth - taking many courses in different fields, and depth - specializing in a particular vocational field. We conduct an analogous disaggregation for core courses (English, math, science and social studies) with the purpose of separating more and less difficult versions of a particular course within a subject. In this case, transcripts identify courses as either "basic", "regular", "Advanced and Honors", "Specialized" and "AP/IB". In this case, lower courses are "basic" or "regular" and higher courses are the remainder.

\footnotetext{
${ }^{4}$ For the wage analysis we construct earned credits as those for which students either received a passing (non-F) or satisfactory mark in the course. For the course-taking analysis credits attempted are the credits a student would have earned had she passed the course. In cases where the number of Carnegie credits is not reported, we impute Carnegie credits as the modal number of credits that a particular student earned in courses in the same field. When a student lacks a comparable course, we then impute to the modal value of all students taking the same exact course title in the same grade in the full sample.
} 


\subsection{Sample definition}

We restrict our sample to exclude those lacking transcripts in all years of high school, those who never completed 9th grade (for whom high school curriculum is not relevant), and respondents with extreme or illogical totals in their transcripts. Specifically, we exclude high school graduates who either (i) had fewer than four years of high school transcripts; (ii) had taken fewer than two courses in each of math, English, science and social studies; or (iii) had more than 36 or fewer than 20 total credits. For high school dropouts, the limiting conditions are necessarily more relaxed as any small number of credits can be consistent with dropout. Thus, for dropouts we restrict to those who (i) completed at least 9th grade; (ii) had taken at least one-half course in math, English, science and social studies; and (iii) had taken more than four total credits ever. The resulting "Analysis sample" used to study curriculum choice and postsecondary outcomes includes 4,414 respondents. Lastly, we restrict wage analysis to a "Wage sample" of 3,708 students whom we determined entered the labor market and with a valid wage record. To determine labor market entry we use monthly enrollment arrays from the NLSY97 and determine enrollment in each semester (fall, spring). We then define labor market entry as the first of four consecutive non-enrolled semesters that are followed by no more than one enrolled semester thereafter. ${ }^{5}$ In specification checks following our main analyses we show that relaxing these assumptions does not alter our results.

Table 1 compares the Analysis and Wage samples to the full NLSY among a broad set of demographic characteristics. Comparing columns 1 and 2 shows that the Analysis sample is slightly more advantaged than the full NLSY, but that on average is representative of the NLSY in whole. Importantly, differences between the two are largely determined by whether NORC could retrieve transcripts, rather than any behavior of the respondent herself. A comparison of columns 2 and 3 shows that the Wage and Analysis samples are nearly identical with few respondents lost between the two. Our empirical exercises focusing on

\footnotetext{
${ }^{5}$ These definitions are taken from Kreisman \& Rangel (2015) who also use NLSY data. We do not restrict wage observations by the number of hours worked, but in a robustness check we restrict to $30+$ hour per week jobs and find nearly identical results.
} 
wages pool multiple observations for each individual over time, resulting in 19,029 personyear observations. In our evaluations of idleness, we use the same 3,708 respondents but include all person-year observations, not only those with wages, after age 18 resulting in a sample of 44,774. Approximately one-third of our Analysis sample obtain a four-year college degree, one-third attend college without earning a degree, 8 percent earn a two-year degree, 19 percent obtain a high school diploma but no post-secondary education, and 3 percent do not graduate from high school.

[Table 1]

\subsection{The distribution of course-taking}

We begin here by highlighting the fact that nearly all students take some vocational coursework - approximately $95 \%$ as shown in Table 1 . We also show that on average students take 3.3 year's worth (the equivalent of 3.3 year-long, one hour per day courses) of vocational coursework, equal to about $12 \%$ of their 25.5 total credits. On average, students take just shy of one of these 3.3 vocational credits in an upper level, or work experience course.

How does this compare with non-vocational course-taking? Figure 3 shows the distribution of credits taken by field demonstrating not only considerable variation in vocational courses compared with other core and non-core coursework, but also visually demonstrating that the modal value is greater than zero. The extent of vocational coursework taken by U.S. high school students relative to traditional academic subjects, even among the most academically-oriented, has not been previously appreciated. Importantly, we interpret the smoothness of the distribution of vocational course-taking in Figures 2 and 3 as confirmatory evidence of our treatment of vocational education as a marginal decision as opposed to a discrete choice of "track".

Figure 4 depicts the average number of courses taken by our sample in each vocational category. The most common types of vocational courses taken are transportation \& industry, business and management, computer technology and keyboarding, and general (labor 
market preparation - GLMP). (Table A1 in the Appendix describes the full list of vocational courses in the NLSY97.) Advanced vocational courses are offered and taken in each of these categories except for general labor market preparation and keyboarding. Given this substantial heterogeneity in high school curriculum, it is natural to investigate the sources and consequences of this variation.

[Figure 3]

[Figure 4]

\section{Choices: Explaining Course-taking Behavior}

\subsection{Descriptive evidence: Course-taking}

We now turn our attention to the predictors and temporal pattern of vocational course taking in high school. Figure 5 presents the average number of courses taken by subject, separately by grade. Though English and foreign language are taken with the same frequency at all grades - students take about one English credit (i.e. one full year) and 0.5 language credits per year, on average - others exhibit strong time trends. For instance, vocational courses are taken with much greater frequency in 11 th and 12 th grades, as students approach graduation and ostensibly have more control over their schedules. Social studies courses exhibit a similar, though weaker, trend. On the other hand, math and science course-taking drops considerably in 12th grade. This suggests that there exist opportunities for students' experiences early in high school to inform later curriculum choices, and that students specialization in vocational coursework has a distinct temporal aspect. This temporal pattern is an important feature of our conceptual model, where early course outcomes inform beliefs about ability and subsequent decisions.

Figure 6 plots the number of credits taken by subject area separately by AFQT quartile. Though total credits are comparable across AFQT scores, there exists substantial variation 
in subject mix. Vocational courses and foreign language courses exhibit the most noticeable relationship with AFQT. High AFQT students take about two-thirds as many vocational courses as low AFQT students and about three times as many foreign language courses. Higher AFQT students also tend to take more science courses. It is important to note that for most students the AFQT is administered during their high school careers - the mean and median respondent took the AFQT approximately at age 14.5 and nearly all had take the test by age 16 - thus we cannot rule out the impact of course-taking on the AFQT itself. On the other hand, the AFQT is likely not informed by the most salient tradeoff with vocational coursework: language courses. That is, the AFQT tests only mathematical and English language ability, not foreign language skill or science. Thus, if vocational courses pull students out of foreign language, science or social studies courses, we should expect to see no effect on AFQT, allaying concerns about timing.

[Figure 5]

[Figure 6]

\subsection{Empirical specification: Course-taking}

To examine predictors of vocational course taking more rigorously, we estimate reduced-form linear regression models using the number of credits taken in each subject, $j$, as the dependent variable. In each specification we focus on vocational courses taken in 10th-12th grade, as there are greater opportunities for students to choose vocational courses after freshman year and this allows us to model choice in grades 10-12 as a function of revealed ability (grades) in 9 th grade. ${ }^{6}$ Guided by the theoretical framework outlined earlier, we are interested in three classes of explanatory variables, which we enter into Equation 3 below sequentially. First, we include a vector of observable student characteristics, such as gender, race, and family background as described in the summary statistics tables. Second, we include AFQT

\footnotetext{
${ }^{6}$ Results are similar if we include 9th grade course-taking in columns 1-2.
} 
as a measure of academic ability. Lastly, as we expect curriculum decisions to be influenced by new information about students' "fit" with academic or vocational curricula, we also include measures of academic performance in math and English in 9th grade, $G P A_{i}^{\text {core } 9^{\text {th }}}$, and a control for whether the math or English courses were high (difficult) or low level, High $/$ Low $_{i}^{\text {core } 9^{\text {th }}} .{ }^{7}$ Though students have prior beliefs about their fit with different curricula, performance early in high school provides additional information with which expectations can be revised. Students that perform well in early core academic subjects might then pursue a more academic (or less vocational) curriculum. Lastly we include $\tau_{s c}$, a full set 9th grade cohort $(c)$ by state of residence in 12th grade $(s)$ fixed effects. That is, comparing within students who entered 9th grade in the same year and who lived in the same state in 12th grade, when the bulk of vocational coursework is taken. Our empirical specification is:

$$
\text { VocCredits }_{i}=\gamma_{0}+\gamma_{1} X_{i}+\gamma_{2} A F Q T_{i}+\gamma_{3} G P A_{i}^{\text {core } 9^{\text {th }}}+\gamma_{4} \text { High }_{\text {Low }} \text { core9 }^{\text {th }}+\tau_{s c}+\varepsilon_{i}
$$

The estimated parameters combine several of the structural parameters described in the dynamic model. In particular, the relationship between AFQT and number of vocational credits taken $\left(\gamma_{2}\right)$ combines the effect of ability on expected performance in high school and college (which influences the flow utility from curriculum), on the likelihood of college graduation, and on labor market outcomes. Thus, the fact that high ability students are less likely to take vocational courses may be explained by any of these mechanisms. Similarly, we interpret $\gamma_{3}$ as the importance of new information revealed about "fit" with an academic curriculum in the form of 9th grade GPA.

\subsection{Results: Course-taking}

Table 2 presents results from Equation 3 above. As prior work has documented, we find that male students and those from disadvantaged backgrounds (mother has high school degree

\footnotetext{
${ }^{7}$ Including math and English GPA's separately yielded empirically equivalent results.
} 
or less, low income, received public assistance) are more likely to take vocational courses. We also find that rural and southern students take more vocationally oriented coursework. Vocational course-taking also decreases sharply with measured ability (AFQT). This is true even when high school dropouts are excluded in specification 4.

As noted above, vocational course-taking has a strong temporal dimension: it is taken largely in 10th and 12th grade. Thus, information revealed during high school could potentially influence course-taking decisions over time. We test this in specification 3, which includes 9th-grade GPA in math and English as a covariate plus controls for whether these courses were upper or lower level, and specification 4 which restricts to only H.S. graduates. We find that students performing poorly in these academic subjects, conditional on our rich set of covariates, are more likely to take vocational courses later in high school, even controlling for AFQT. That is, a one-point increase in 9th-grade math and English GPA decreases total vocational course taking by 0.15 of a one-year course. This represents a roughly 5 percent decrease in vocational course-taking off of a base of approximately 3 total vocational courses on average. This result is consistent with a key aspect of our theoretical framework, where students use early course performance to update their beliefs about their fit with the academic/college sector or vocational/non-college tracks, and these beliefs in turn influence course-taking. In column 5, we include a full vector of cohort-state fixed effects to observe whether state level variation in either vocational course offerings, graduation requirements, or state-level labor market conditions might affect the relationships we observe. Adding these fixed effects reduces the minority and income gradients, but has little impact of the relationship between 9th grade GPA, or AFQT, and course-taking, suggesting that this type of variation is not the primary driver of course-taking behavior.

The final two columns present estimates separately for low and high vocational coursework respectively. Results in these final two specifications reveal a subtle yet important distinction - that ability and freshman year GPA, in addition to many of the fixed demographic characteristics we observe concerning childhood circumstances, are far more predictive of tak- 
ing low-level vocational courses than they are of upper-level or specialized vocational courses. In particular, we find that a negative signal of ability manifested in low grades in core courses in 9th grade, conditional on course level and AFQT, increases the number of low-level vocational courses in grades 10-12, but has no impact on taking upper level, or specialized, vocational courses. Put differently, low ability, or learning about low ability, leads students to take a broader array of vocational courses rather than to specialize in a particular type of vocational training. The importance of this result is underscored in subsequent analyses below demonstrating that (i) while lower level vocational courses deter students from college, upper level courses at worst do no harm, and (ii) that while upper level vocational courses benefit students in the labor market, low-level vocational courses have no impact.

[Table 2]

\section{Outcomes: College and the Labor Market}

\subsection{Empirical specification: College attendance and completion}

We begin our analysis of the consequences of high school vocational coursework by observing the relationship between high school curriculum choice and both college attendance and completion. To do so, we first estimate three linear reduced form equations where the dependent variable, College, is a binary indicator of college attendance in a two-year college, a four-year college and then any college. We then repeat this exercise for college completion conditional on college enrollment. In both cases we condition on having completed high school though results are similar if not. Our main explanatory variables, VocHigh $h_{i}$ and $V_{o c L o w}$, measure the number of high and low vocational credits earned during high school. Since number of vocational credits is likely correlated with credits earned in other subjects, we control for a vector of credits earned in core (high and low) and elective subjects (language, art/music, 
PE, and "other" courses) as defined below.

$$
\begin{aligned}
\text { College }_{i} & =\beta_{0}+\beta_{1} \text { VocLow }_{i}+\beta_{2} \text { VocHigh }_{i}+\beta_{3} \text { CoreLow }_{i}+\beta_{4} \text { CoreHigh }_{i}+\beta_{5} \text { Elect }_{i} \\
& +\beta_{6} X_{i}+\beta_{7} \text { AFQT }_{i}+\tau_{s c}+\epsilon_{i}
\end{aligned}
$$

While it is important to note that in most cases students taking upper level vocational courses take these after taking an introductory vocational course, as demonstrated above most students in fact take multiple vocational courses. Thus, we are comparing students who choose to take several different introductory vocational courses with those who take their courses in a linear sequence. For example, on average students take just over two low level vocational courses (that is, two one-year courses) and one upper level vocational course. We verify this further in our robustness specifications.

\subsection{Empirical specification: Wages}

To examine labor market consequences of vocational course taking we stack wage observations and estimate reduced-form linear regression models that exploit cross-sectional variation in high school course-taking. Our primary labor market outcome is the log of (real) hourly wage, which is observed at multiple ages and thus pooled across all observations for individuals in our wage sample. We begin by including only VocHigh $h_{i}$ and $V_{o c L o w}$ and then sequentially include additional covariates to observe how estimates change when non-vocational coursework $\left(\right.$ Core $_{i}$, Elect $\left._{i}\right)$, ability $(A F Q T)$, and college attendance and completion $\left(\right.$ Postsec $\left._{i}\right)$ are accounted for. The inclusion of either of these types of controls (nonvocational courses and postsecondary outcomes) alters the interpretation of the estimated parameters and thus is an important modeling choice, a subject we discuss more thoroughly in the next subsection. Our preferred specification is then:

$$
\begin{aligned}
\ln \left(\text { wage }_{i t}=\beta_{0}\right. & +\beta_{1} \text { VocLow }_{i}+\beta_{2} \text { VocHigh }_{i}+\beta_{3} \text { CoreLow }_{i}+\beta_{4} \text { CoreHigh }_{i}+\beta_{5} \text { Elect }_{i} \\
& +\beta_{6} X_{i}+\beta_{7} \text { AFQT }_{i}+\psi \text { Postsec }_{i}+\tau_{s c}+\phi_{t}+\epsilon_{i t}
\end{aligned}
$$


Our controls $\left(X_{i}\right)$ include all the demographic and high school characteristics listed in panels A and B of Table 1, as well as cohort by state of residence in high school fixed effects $\left(\tau_{s c}\right)$, secular wage-year indicators $\left(\theta_{y}\right)$, indicators for region of residence and MSA status at interview, and an indicator for enrollment. All specifications account for the within-individual correlation across observations by clustering standard errors on the individual.

\subsection{An aside: Course substitution, postsecondary outcomes and the interpretation of parameter estimates}

Since students' time is fixed, one substantive modeling choice is whether and how to control for the number of credits earned in other subjects. Without controls for other courses - i.e. core courses and electives - the parameters $\beta_{1}$ and $\beta_{2}$ in Equation 5 should be interpreted as the ceteris paribus change in log wage associated with an additional (high or low) vocational credit. Since each additional vocational course could be taken at the expense of another course

(math, language, science, etc.), or what would otherwise be non-course time, the nature of the treatment likely varies across the population. The three panels in Figure 7 depict the implicit nature of the tradeoff between vocational and other types of courses. Vocational courses are most clearly traded off with electives (art/music, foreign language, physical education, and "other" courses). The correlation between vocational and core academic courses (English, math, science, and social studies) is also negative, but much weaker. Thus, the "average treatment" in the model without controls for other courses can be thought of as taking one vocational course but fewer electives.

Controlling for number of credits taken in other subjects alters this interpretation. As a thought experiment, imagine that we divided courses into three types: core, vocational and electives, and then for each respondent determined what share of total coursework each constituted. Including all three measures in our empirical specification would violate the full rank assumption (perfect collinearity) and one term would have to be omitted in the regression equation. Thus, holding course-taking in all other subjects constant, the parameters $\beta_{1}$ 
and $\beta_{2}$ should be interpreted as the outcome change associated with taking one more high or low vocational credit at the expense of what would otherwise be non-course time, controlling for selection on observables. That is, the full rank assumption relies empirically on variation in the total number of courses taken across students. In this case, the opportunity cost of an additional course depends on how students potentially use this marginal hour among available activities, such as study hall, paid or volunteer work, homework, or leisure. Furthermore, controls for course taking in other subjects may also account for additional forms of selection if course-taking in other subjects is a marker for traits influencing outcomes that also correlate with vocational course-taking.

[Figure 7]

Surprisingly, prior literature on the effects of course taking is mostly silent on this important conceptual issue, with the exception of Altonji (1995). His models include number of credits taken in eight subjects (English, social studies, math, science, foreign language, fine arts, industrial arts, and commercial), omitting time devoted to study halls, certain vocational courses, PE, and home economics. He concludes that "one would expect all the elements of [the coefficient vector] to be greater than or equal to 0," since the specification controls for any displacement effects on other course-taking. In examining the labor market effects of math courses, Rose and Betts (2004) do not mention non-math course taking (in vocational, other academic, or elective courses) as the primary opportunity cost of taking an additional math course. Their main empirical model includes the number of math courses in six different levels and thus each coefficient should be interpreted as the effect of taking more courses in one level of rigor holding constant the number of math courses in the other levels. In these models students are explicitly trading off math course-taking with time allocated to other subjects or non-school time - which of these, though, remains unclear. Subsequent specifications include number of courses in English, science, and foreign language, also using detailed curriculum categories. Interpreting the coefficients in these models is difficult because an additional year spent in upper-level English, for instance, may have a 
different opportunity cost against which the effect is measured than one spent in basic Biology. Goodman (2012) shows that curricular reforms have a moderate and significant impact on math course-taking, but also a modest insignificant impact on other course-taking. His two-sample instrumental variables estimates of the wage effects of math courses implicitly assumes that reforms cannot impact wages through these non-math courses either because reforms do not affect non-math course-taking or because such courses have no labor market impact. In our preferred model we follow in the spirit of Altonji (1995) and include a vector containing number of credits earned in all other subjects, but show similar specifications with only vocational credits included. In an ancillary set of regressions we model the share of courses taken in each subject, leaving electives as the omitted category, and including a continuous measure of the total number of courses taken. While directionality in each of these specifications is similar, leading to similar policy conclusions, for reasons mentioned above interpretation differs.

\subsection{Results: College attendance and completion}

Before examining labor market outcomes, panel A of Table 3 shows conditional mean differences in postsecondary attendance and completion across high school course-taking as described in Equation 4. Note that here we restrict only to high school completers to avoid confounding the number of credits taken with graduation. Results are nonetheless robust to their inclusion. We find little relationship between vocational coursework and college attendance on aggregate - resulting from opposite signed coefficients on two-year college (positive) and four-year schools (negative) for upper level vocational courses and point estimates near zero for low level vocational courses. As expected, we find that students taking more core and elective credits are less likely to attend two-year colleges and more likely to attend four-year institutions.

Repeating the same exercise in columns 4-6 for respondents who attended two- or fouryear college as their highest grade suggests that there is little observational evidence that 
vocational courses decrease graduation rates for those enrolled. In fact, we find evidence that, conditional on enrollment, students earning more upper level vocational credits are more likely to graduate by nearly two percentage points.

In panel $\mathrm{B}$ of Table 3 we replicate our model using the share of credits accumulated in each field and include an additional control for the total number of credits accumulated (estimating the same model without total credits yields empirically similar results). In this case, as an actualization of the thought experiment described above, we omit the share of courses that were electives to satisfy the full rank requirement. Results are largely similar to panel A. We find that while increasing the share of low vocational courses decreases college attendance for four-year schools, increasing the share of courses dedicated to specialized, or upper level, vocational course-work increases enrollment to two-year schools and decreases four-year enrollment.

Conditional on college enrollment, we find that those with higher shares of coursework dedicated to introductory vocational courses are marginally less likely to earn a degree on an order of about a 3 percentage point decrease for each 10 percent increase in the share of courses that are introductory vocational. These conflict with results in panel A, which showed no relationship, highlighting the importance of credits vs. shares. Nonetheless, these coefficients in panel B are small and marginally different from zero. We also find that those with larger shares of upper level vocational coursework are marginally more likely to graduate from two-year schools by about 6 percentage points for each 10 percentage point increase in upper vocational share.

Taken together, these results suggest that vocational courses may deter the marginal student from college, at least as measured by shares, but that there is little aggregate impact on graduation rates conditional on enrollment. Put differently, vocational courses may pull those students out of college who may be least likely to graduate. Though noisy, this is suggestive of a learning process where vocational coursework provides students with valuable labor market skills and additional information about their comparative advantage in the 
vocational or college labor market. An alternative explanation is that the opportunity to take vocational course-work compels some students to graduate from high school, but that these students are unlikely to attend college. This would result in lower college enrollment rates, but college graduation conditional on enrollment will be unaffected as the marginal high school graduate is unlikely the marginal college attendee.

Finally, we draw attention to the coefficient estimates on core and elective course-taking. In particular that taking additional courses, or increasing shares in these courses, increases the likelihood of both college enrollment and completion. While this is not surprising, we highlight this result to tie our earlier theoretical prediction with the wage regressions we present below. In particular, that the labor market value of non-vocational coursework operates through increased college attendance.

[Table 3]

\subsection{Results: Wages and Idleness}

We begin our wage analysis by pooling observations and estimating unconditional correlations between vocational (low and high) course-taking and log hourly wage of employed NLSY respondents in Table 4. We find that, as expected, those earning more low level vocational credits earn less - about $2 \%$ per year of low vocational coursework. This is not surprising since high school graduates who take more of these courses tend to be lowerachieving and more disadvantaged, attributes that have independent effects on labor market outcomes. Conversely, we find a positive relationship between upper level vocational coursework and earnings on the order of a $1 \%$ increase with each additional year of coursework. We next include our full set of covariates (excluding AFQT) finding that indeed accounting for childhood circumstances, school type and a host of other controls both explains away the entirety of the negative relationship between low vocational coursework and wages, and increases the observed wage gains associated with upper level vocational courses. 
We next include the AFQT, a commonly used proxy of "ability", in the model. We know from summary statistics that students with higher AFQT scores take fewer vocational courses, suggesting that its inclusion might increase the observed relationship between vocational coursework and wages. Yet, specification 3, which includes AFQT, does not affect results.

We also might think that more vocational coursework crowds-out academic subject or electives, which might affect wages as well. Column 4 then controls for the number of credits earned in other subjects, separating elective and core academic subjects (math, English, science and social studies) and omits AFQT for the time being. This specification also distinguishes high- and low-level academic subjects (e.g. advanced algebra vs. basic math). Consistent with results in Rose and Betts (2004), advanced coursework is much more advantageous than basic coursework. Comparing columns 2 and 4, the coefficient on advanced vocational work does not change, suggesting that vocational course-taking does not crowd out other courses which also have impacts on wages (not conditioning on college or AFQT). Alternatively, credits earned in other subjects may be a marker for academic ability which further controls for the negative selection bias. Since these factors may offset, we are not able to distinguish these two distinct channels. Controlling for all factors in column 5 reconciles this yet has little impact on results other than reducing the gain to upper-level core courses by one-third. In other words, selection on ability, at least as measured by AFQT, does not appear to affect the observed relationship between vocational coursework and wages conditional on our full set of controls.

We next address concerns that the local education environment, for example graduation requirements, labor markets, state-level vocational funding or state/cohort-level attitudes toward vocational education, might bias our results. To account for this, we include a full set of cohort by state of 12 th grade attendance fixed effects. We find that their inclusion has little impact on results, suggesting that concerns about the local environment biasing our results are not immediate. 
Lastly in column 7 we add controls for post-secondary attendance and attainment. As expected, we find that the majority of wage gains associated with core coursework are explained by controlling for higher education and an ability proxy. In fact, the 2 percent upper core course advantage is more than halved and signs on lower core and electives are now negative, though indistinguishable from zero. Yet, we find that the positive wage gains associated with additional upper level vocational courses are unaffected by the inclusion of these factors, suggesting a 1.8 log point wage premium for each additional year of upper level vocational coursework. We take this as prima facie evidence that the labor market value of vocational coursework accrues largely to non-college graduates, and that the labor market value of non-vocational coursework is largely if not entirely explained by its contribution to post-secondary attainment.

In sum, our estimates suggest a near 2 percent wage gain associated with each additional year of upper level vocational coursework, yet no gain is associated with increasing breadth in introductory vocational courses. We take this as evidence of gains to specialization in high school labor market training. Moreover, these results persist conditional on a measure of non-technical labor market skill in the AFQT, a host of student level controls including parental income, state-cohort fixed effects, parent's education, high school type and urban/rural designation in adolescence.

\section{[Table 4]}

[Table 5]

As a specification check in Table 5 we repeat our preferred specification from Table 4 using an alternative specification modeling the share of courses taken rather than the count as we did in panel B of Table 3. Again results largely confirm our preferred specification, but with a different interpretation. In Table 5 we estimate that a one percentage-point increase in the share of upper level vocational courses increases wages by just over one-half of one percent, even after accounting for our full set of controls. To put these results in comparable 
terms, we estimate the change in share of courses associated with a one course increase by regressing the share of upper level vocational courses on the number of vocational courses taken, finding that one extra course is equivalent to a nearly four percent increase in the share of courses taken. Since students in the wage sample take roughly 25 courses on average, where a one course increase is equivalent to a four percentage-point change, this confirms our intuition of a tradeoff with elective courses. Multiplying this four percentage-point increase by the 0.006 coefficient estimate suggests a 2.4 percent increase in wages - larger but similar in magnitude to the 1.8 percent increase estimated in the credit count model in Table 4, suggesting that these results do not rely heavily on functional form assumptions.

Above we explicitly consider wage gains as opposed to earnings differentials, where the latter also account for non-employment. To round out our analysis on labor market outcomes we estimate a modified version of Table 4 with a binary indicator for idleness as the dependent variable - defined as neither working nor in school. ${ }^{8}$ With no need to limit the sample to those entering the labor market or to those employed, we use our entire analysis sample of 4,414 individuals and limit to observations on or after age 19, when ostensibly all are out of high school.

Moving across columns 1-3 of Table 6 shows the effect of adding sequential sets of control variables on the relationship between course-taking and idleness, as in Tables 4 and 5, with similar results. With a full set of controls in column 4, we find little relationship between idleness and vocational coursework of any type. Yet, disambiguating the sample between those who ever attended college and those who never attended shows that students who never attended college and took more upper level vocational coursework were less likely to be idle, on the order of a 1.3 percentage point decrease in the incidence of idleness for each year of upper level vocational coursework and 0.08 percentage point for each low level course. There is little relationship between core or elective credits and idleness for non-

\footnotetext{
${ }^{8}$ We estimate the model using OLS as we include a large number of state-cohort fixed effects, which induces bias in non-linear models. We verify that the linearity assumption does not change results by reestimating the model without the fixed effects both using a logistic regression and OLS.
} 
college students. When we restrict the sample to students who attended any college, we find no relationship between idleness and high school vocational coursework, suggesting that decreased idleness is attributable to increased employment and exclusively for students who do not attend post-secondary schooling.

[Table 6]

\subsection{Exogenous variation in course-taking}

Our theoretical framework implies that students sort into vocational coursework. Thus, we do not interpret our results in Tables 4 and 5 as the causal effect of vocational coursework on wages. Rather, we interpret these as wage gains associated with completing additional coursework. This distinction is important for two reasons. First, high school curriculum is becoming increasingly prescribed, meaning that increasing graduation requirements that induce students who would have taken (upper level) vocational courses to take fewer may not be welfare enhancing. Further, states are moving toward a model of vocational coursework where students complete "pathways", usually a sequence of 3 courses aligned with skills in a specific industry or occupation. Thus, while CTE courses are being squeezed by other graduation requirements, CTE itself is focusing more on depth as opposed to breadth. Second, the distinction clarifies a key misconception about vocational coursework: that it is a "dumping ground" for low ability or low effort students leading to "dead end jobs." Negative selection into meaningless courses is unlikely to result in the positive estimates we find above.

To provide additional support for our argument we employ school-level graduation requirements as a source of variation in course taking. This allows us to purge selection from the gains associated with additional courses. The NLSY Geocode data provides researchers with school level graduation requirements as reported by NLSY97 respondents' schools in the same survey that collected their high school transcripts. These include courses required for graduation in English, mathematics, social studies and science, along with the total number of courses required. For this portion of our analysis we omit 423 respondents who have 
missing values for any of the graduation requirements, and an an additional 510 for whom the requirements were imputed at the state level by the NLSY as opposed to reported by the school; we verify that this does not drive results.

We have three hurdles to overcome to make claims from our instrument(s). First, that course requirements affect the outcome (wages) only through the measure they instrument for (course taking); i.e. that it is excludable. While there is no way to test this formally, we do not see how increasing, say, the number of required math courses would affect an individual's wage other than through additional math coursework (and thereby possibly fewer courses in other subjects). One counter argument might claim that increasing the number of required math courses for all students would depress the price of mathematics skill in the labor market by shifting outward the supply of this type of skilled labor. While we believe this argument is reasonable, since we are comparing students within labor markets, this type of general equilibrium effect should be absorbed by local labor market controls.

Second is the monotonicity assumption, that the instruments work in the same direction for all individuals. In this case this would mean that increasing math requirements may induce some students to take more math (the compliers), and may leave some unaffected (always-takers), but induces no students to take fewer math courses. This is reasonable in the one instrument, one endogenous variable case, but might be more subtle in the multiple instrument, multiple IV case as we apply here. To illustrate, we begin with a simplified version of Equation 5 above where the high/low designations are collapsed into 3 course types as below:

$$
\ln (\text { wage })_{i t}=\beta_{0}+\beta_{1} \text { Voc }+\beta_{2} \text { Core }+\beta_{3} \text { Elect }+\beta_{4} X_{i}+\beta_{5} A F Q T_{i}+\psi \text { Postsec }_{i}+\tau_{c s}+\phi_{t}+\epsilon_{i t}
$$

We want to instrument for each of our endogenous variables, Voc, Core and Elect, thus we need three instruments. We could estimate a model where we only include $V o c$ but worry that this might violate the excludability assumption. That is, if we instrument for the number of vocational courses using math requirements, assuming increasing math requirements induces 
students to take fewer vocational courses, it would have to be the case that increasing math requirements only affect wages through reducing vocational course-taking. This is likely not the case since we would naturally expect an increase in math course-taking as well, which in turn could affect wages. Thus we include all three course categories and identify an equal number of instruments. ${ }^{9}$ Then, our three first-stage equations are as follows:

$$
\begin{gathered}
V o c=\alpha_{0}+\Pi X_{i}+\Gamma_{V}(\text { ReqMath, ReqSoc, ReqTot })+\Delta \text { Degree }+\tau_{c s}+\phi_{t}+\epsilon_{i t} \\
\text { Core }=\alpha_{0}+\Pi X_{i}+\Gamma_{C}(\text { ReqMath, ReqSoc, ReqTot })+\Delta \text { Degree }+\tau_{c s}+\phi_{t}+\epsilon_{i t} \\
\text { Elect }=\alpha_{0}+\Pi X_{i}+\Gamma_{E}(\text { ReqMath, ReqSoc, ReqTot })+\Delta \text { Degree }+\tau_{c s}+\phi_{t}+\epsilon_{i t}
\end{gathered}
$$

The monotonicity assumption then presumes each course requirement affects each course category in the same direction. A violation would be, for example, if increasing math requirements led some students to take more vocational courses and others to take fewer (having no effect on any student is not a violation of monotonicity). Although theoretically possible, we cannot see why increasing the number of social studies and math requirements would result in someone taking more vocational courses since, mechanically, this reduces the available number of hours in a semester for additional coursework of any type.

Third, we need to show that our instruments affect our covariate of interest, which we do in our first-stage estimates. Predicted values from the first stage, $\widehat{\Gamma}_{(V, C, E)}$, are then used in the second-stage equation. Since we use multiple instruments, we report Angrist-Pischke F-statistics which account for the multiple endogenous variables and multiple instruments. Results from first-stage Equations 7a-c are shown in Table 7. Focusing on vocational coursetaking in column 1, results indicate that increasing the total number of courses required for graduation increases vocational course-taking, while increasing the number of socialstudies requirements decreases attendance in these courses. We find that the F-statistics for vocational and elective credits are above commonly used thresholds, though the instruments'

\footnotetext{
${ }^{9}$ Although we have 5 potential instruments (English, math, science, social studies and total course requirements), using all of these on the full set of course measures including the high/low course designations was underpowered.
} 
effect on core courses is considerably week.

Table 8 shows results from Equation 6 using predicted values from the first stage for each course type. We begin by reestimating the full specification from our reduced form wage equation in column 1, this time collapsing the high/low designations leaving three categories: vocational, core and electives. As expected, we see some positive benefit from vocational coursework as a weighted combination of low and high vocational courses, and neither benefit nor harm from electives and core courses. We then repeat this specification in column 2 but limit to the IV sample to confirm that omitting respondents with missing or imputed statelevel graduation requirements does not drive results. Lastly, in column 3, we show results from our IV specification. While noisy, we find that the sign on vocational coursework flips from positive to negative. While not conclusive, this suggests that students compelled to take additional vocational courses (compliers) due to high total course graduation requirements coupled with relatively low social studies and math graduation requirements likely see no benefit from these additional courses.

Multiple instruments are difficult to interpret so we do so here with caution. We take these results as suggestive evidence of the positive selection story, (though we point out that imprecise estimates, due to multiple weakly powered instruments, cannot rule out positive effects as well). That is, students who choose to enroll in vocational coursework see earnings gains, while those induced to enroll due to graduation requirements see no benefit. This would be a likely result if those who are induced into vocational coursework due to graduation requirements enroll in additional entry level vocational classes. In either case results here, combined with results in Table 4, suggest that policies limiting (upper level) vocational coursework for students who would have enrolled otherwise would negatively impact wages, in particular for those who never attend college.

[Table 7]

[Table 8] 


\subsection{Heterogeneity, Sensitivity and Alternative Hypotheses}

We next turn our attention to heterogeneity in wage gains and sensitivity to alternative hypotheses, model specifications and sample selection. We begin by decomposing observed wage gains by vocational field of study, though sample size constraints prohibit us from a full set of interactions between occupational field and high/low denomination. Results are shown in Table 9 where coefficients are ordered from the most to least frequented vocational courses. We find that gains are driven by Transportation \& Industry (including construction trades, mechanics and repair, transportation and production), Business \& Management (including business management, services and marketing), and Health Care. Notably, Transportation \& Industry and Business are the most frequented vocational fields. We find large and negative coefficients on Industrial Arts as classified as General Labor Market Preparation, meaning introductory coursework. The NLSY does not provide details on which courses were included, but only two percent of respondents earned any credits in this field. No other fields have negative coefficients that are statistically different from zero. We also find no gain from either Keyboarding, a non-trivial finding considering that computer access was far from universal in the late 1990's and early 2000's when NLSY respondents were in high school, or from Computer Technology. These results highlight the heterogeneity in gains associated with vocational coursework both in terms of specialized vs. introductory coursework, and across fields of specialization.

Having decomposed aggregate gains both by field and by specialized vs. introductory coursework, we now turn to a series of specification checks. While we have shown various iterations of our main wage specification in the tables above, we are also interested in testing sensitivity to different definitions and samples. To do so we begin in Table 10 by re-estimating our preferred wage specification from column 6 of Table 4 . In column 2 we address concerns that accounting for state-by-cohort level variation is insufficient as course-taking might be

more largely influenced by local (school district) conditions. While the data does not allow us 
to compare within schools, in specification 2 we replace our state-by-cohort fixed effects with county-by-cohort effects, allowing us to compare students in the same 9th grade cohort who attended 12 th grade in the same county. This addition has little impact on estimates and no impact on interpretation. While one might still worry that there exists considerable variation in school environments and attitudes toward vocational coursework within counties, we note that we are also accounting for measures of childhood wealth, maternal education, gifted and bilingual schooling, whether students went to a private high school, urban/rural status at age 12 and measures of academic ability in addition to coursework in core and elective fields. To further verify this, in column 3 we add our full set of graduation requirements (English, math, social studies, science and total credits) to the model to ensure that school-level variation in graduation requirements is not driving results. Again we find no change to our estimates, likely due to the fact that these effects are absorbed by our state- or county-cohort fixed effects.

In column 4 we then relax our sample restriction which excluded students with illogical or unusually large/small total credit counts. Results are unchanged. In column 5 we then restrict our wage observations to only those over age 23 - when the vast majority of students have completed formal schooling. Again, results are unaffected. In column 6 we then restrict to those working 35 hours per week or more, again finding no change to results. In column 7 we address concerns about the way in which vocational credits are counted by high schools. In particular, the NLSY's documentation notes that the weighting scheme for certain vocational and enrichment courses in can differ from those of academic coursework in a manner that would inflate the total number of Carnegie credits earned. ${ }^{10}$ While we address this in our original sample selection criteria, omitting respondents with unusually high credit counts, we further test for sensitivity here by restricting to respondents who earned no more than four Carnegie credits in vocational coursework with little change to results. Note also that the

\footnotetext{
${ }^{10}$ The codebook supplement can be accessed at: https://www.nlsinfo.org/content/cohorts/nlsy97/ other-documentation/codebook-supplement/appendix-11-collection-transcript (as of December, 2016).
} 
systematic inflation of the count of vocational coursework would serve to underestimate the true relationship. Any case where this relationship is caused by state-wide reporting rules would be accounted for by state-level fixed effects. The only concern would be cases where differential weighting is correlated with unobserved factors correlated with both the number of actual courses taken and earnings, which we find unlikely.

Finally, in columns 8 and 9 we turn our attention to alternatives to our "upper/lower" vocational coursework definition. To do so, we replace our course-level measures with indicators for Vocational Concentrator and Vocational Specialist. The NLSY defines a concentrator as someone who has earned at least 3 Carnegie credits in a single labor market field. Specialists are those earning at least 4 credits in a specific field, with at least two of these coming from upper level courses. In column 8 we replace our continuous low and high measures with these dichotomous and mutually exclusive measures that specifically measure vertical credit accumulation (depth) as opposed to horizontal vocational credit accrual (or breadth) in vocational coursework. Results are consistent with our claim of the value of depth over breadth - we find that concentrators see a small wage premium of $3.2 \%$ while specialists experience a $6.2 \%$ wage premium. In column 9 we include both designations for Concentrator/Specialist and credit counts, finding that we still see a statistically significant relationship between specialized vocational coursework and wages.

To further demonstrate that those students taking a large number of low level, or introductory, vocational courses are indeed experiencing breadth as opposed to racking up multiple low level credits in a single field, we plot in Figure 8 the relationship between the number of low level vocational courses taken and the number of different vocational fields in which students took vocational coursework. Were the majority of students simply accruing multiple low level courses in a single field (a different measure of depth) we would expect a flat relationship between credits and the number of fields experienced. We find that this is not the case. For example, students who take 3 Carnegie credits of low level vocational coursework experience on average nearly 3 different fields, suggesting that indeed our inter- 
pretation of breadth vs. depth is warranted.

We have demonstrated that those taking more specialized vocational coursework see higher wages and lower incidence of idleness in early careers. We attribute this to students sorting into coursework that aligns with their talents and preferences, as self-selection models predict. Further, we have taken several steps to identify possible alternative hypotheses. Primary among these is the negative selection story, where less able students are pushed into vocational coursework. The persistently positive results we observe here are likely inconsistent with this story. Second, one might worry that states or localities where returns to vocational training are (expected to be) higher will offer more, or have better funded, vocational programs. Yet, we find that comparing within state-cohort, or even county-cohort, has little impact on results. Lastly, one might worry that specialization might also include multiple introductory courses within a field. Yet, we show that alternatively defining vocational course-taking by concentrators and specialists yields even larger results, and we also demonstrate that increasing introductory courses corresponds with an increasing number of different vocational fields. In addition, we note that that this is all true conditional on a very broad set of observable characteristics, courses taken in other fields, a measure of ability, and accounting for post-secondary attendance and attainment. As a result, we interpret our findings as strongly suggestive evidence that those students who choose to take vocational coursework see benefits in the labor market to specialized courses, in particular in technical fields and among those who do not earn a post-secondary degree. This does not imply that non-vocational students would benefit from more (specialized) vocational coursework, but it does strongly suggest that were vocational coursework removed from the curriculum, a sizable share of students, in particular those not planning to attend college, would be worse off.

There are caveats to these conclusions, in addition to those mentioned above. Foremost among these is that we only observe the early careers of NLSY respondents - the mean age in the most recent year of the wage sample is 28.5. Recent work by Hanushek, et al. (2016) 
suggests that increasingly specialized training in high school limits workers ability to adapt to changing labor market conditions later in life. A question we and others would be wise to address in future research with a direct focus on the US context.

[Table 9]

[Table 10]

[Figure 8]

\section{Conclusion and Policy Implications}

We weigh in on a long-standing debate over labor market training in American high schools. Our analysis focuses on factors leading students to take vocational courses and how these courses affect transitions to college and the workforce. We couch our analysis within a sorting framework where students learn about preferences for and skill in academic or vocationally oriented (course)work.

Using detailed course-taking and labor market information from the NLSY97, we find that each additional year of advanced vocational coursework during high school is associated with a near 2 percent increase in wages. This result is robust to an extensive set of individual controls for student background, ability, location and cohort effects, for any displacement effects on the completion of other courses and for effects on postsecondary attainment. Yet, we find that each additional course of introductory vocational coursework has no benefit (or harm) in the labor market. We interpret this finding as the value of depth over breadth.

Our analysis reveals several subtle yet sharp distinctions that lead to direct policy implications. First, we find that vocational coursework may have informational value enabling students to make more informed choices about their likely fit with college. Since taking more advanced vocational coursework is associated with lower four-year college enrollment rates but no reduction in college completion, this implies that students induced out of four-year 
college by a vocational secondary curriculum may have been least likely to earn a degree. Early exposure to vocational curriculum may thus facilitate better college enrollment decisions and fewer ex-post "mistakes". Concerns about high student debt among college dropouts has made improving college enrollment decisions an important policy priority. Second, we demonstrate that while wage gains associated with non-vocational courses (core and electives) are entirely explained by college enrollment, wage gains from upper level vocational courses are unaffected by controlling for college enrollment and completion, suggesting that these courses do in fact have value in the labor market. Lastly, we demonstrate that gains accrue to those students who select into vocational coursework. Those induced into additional courses due to graduation requirements see no benefit. These last two points speak directly to criticisms that vocational education is "preparing students for jobs that don't exist," or that it is a "dumping ground" for low ability students. The results we uncover do not support either of these conclusions.

How schools should prepare students for post-graduation - college, the workforce, citizenry - remains a timely policy question. This is nowhere more evident than in the recent shift from "college for all" to "college and career," and in the simultaneous drive toward increased academic standards through the Common Core, and an increasing drive toward workforce preparedness in Career-Tech pathways. The research presented here makes a strong case for keeping vocational education an accessible part of the high school curriculum and that students and policy makers should focus on the value of depth over breadth. 


\section{References}

Agodini, R. and Deke, J. (2004). The relationship between high school vocational education and dropping out. Technical report.

Altonji, J. G. (1995). The effects of high school curriculum on education and labor market outcomes. The Journal of Human Resources, 30(3):409-438.

Altonji, J. G., Blom, E., and Meghir, C. (2012). Heterogeneity in human capital investments: High school curriculum, college major, and careers. Annual Review of Economics, 4(1):185223.

Arcidiacono, P. (2004). Ability sorting and the returns to college major. Journal of Econometrics, 121(1):343-375.

Attanasio, O., Kugler, A., and Meghir, C. (2011). Subsidizing vocational training for disadvantaged youth in colombia: Evidence from a randomized trial. American Economic Journal: Applied Economics, pages 188-220.

Bishop, J. H. and Mane, F. (2004). The impacts of career-technical education on high school labor market success. Economics of Education Review, 23(4):381-402.

Bishop, J. H. and Mane, F. (2005). Raising academic standards and vocational concentrators: Are they better off or worse off? Education Economics, 13(2):171-187.

Cellini, S. R. (2006). Smoothing the transition to college? the effect of tech-prep programs on educational attainment. Economics of Education Review, 25(4):394-411.

Dougherty, S. (Forthcoming). The effect of career and technical education on human capital accumulation: Causal evidence from massachusetts. Education Finance and Policy.

Eichhorst, W., Rodríguez-Planas, N., Schmidl, R., and Zimmermann, K. F. (2015). A road map to vocational education and training in industrialized countries. Industrial \& Labor Relations Review.

Furstenberg Jr, F. and Neumark, D. (2005). School-to-career and post-secondary education: evidence from the philadelphia educational longitudinal study. NBER working paper w11260.

Goodman, J. S. (2012). The labor of division: Returns to compulsory math coursework. John F. Kennedy School of Government working paper, Harvard University.

Gustman, A. L. and Steinmeier, T. L. (1982). The relation between vocational training in high school and economic outcomes. Industrial \&6 Labor Relations Review, 36(1):73-87.

Hanushek, E. A., Schwerdt, G., Woessmann, L., and Zhang, L. (2016). General education, vocational education, and labor-market outcomes over the life-cycle. Journal of Human Resources. 
Hudson, L. (2013). Trends in cte coursetaking. data point. National Center for Education Statistics, NCES 2014-901.

Joensen, J. S. and Nielsen, H. S. (2009). Is there a causal effect of high school math on labor market outcomes? Journal of Human Resources, 44(1):171-198.

Kang, S. and Bishop, J. (1989). Vocational and academic education in high school: complements or substitutes? Economics of Education Review, 8(2):133-148.

Kreisman, D. and Rangel, M. A. (2015). On the blurring of the color line: Wages and employment for black males of different skin tones. Review of Economics and Statistics, 97(1):1-13.

Levine, P. B. and Zimmerman, D. J. (1995). The benefit of additional high-school math and science classes for young men and women. Journal of Business $\&$ Economic Statistics, 13(2):137-149.

Malamud, O. (2011). Discovering one's talent: learning from academic specialization. Industrial \& Labor Relations Review, 64(2):375-405.

Malamud, O. and Pop-Eleches, C. (2010). General education versus vocational training: Evidence from an economy in transition. The Review of Economics and Statistics, 92(1):43-60.

Mane, F. (1999). Trends in the payoff to academic and occupation-specific skills: the short and medium run returns to academic and vocational high school courses for non-collegebound students. Economics of education review, 18(4):417-437.

Maxwell, N. L. and Rubin, V. (2002). High school career academies and post-secondary outcomes. Economics of Education Review, 21(2):137-152.

Meer, J. (2007). Evidence on the returns to secondary vocational education. Economics of education review, 26(5):559-573.

Neumark, D. and Joyce, M. (2001). Evaluating school-to-work programs using the new nlsy. Journal of Human Resources, pages 666-702.

Neumark, D. and Rothstein, D. (2005). Do school-to-work programs help the 'forgotten half'? NBER working paper w11636.

Neumark, D. and Rothstein, D. (2006). School-to-career programs and transitions to employment and higher education. Economics of Education Review, 25(4):374-393.

Rose, H. and Betts, J. R. (2004). The effect of high school courses on earnings. Review of Economics and Statistics, 86(2):497-513.

Rosenbaum, J. E. (2001). Beyond college for all: Career paths for the forgotten half. Russell Sage Foundation.

Stange, K. M. (2012). An empirical investigation of the option value of college enrollment. American Economic Journal: Applied Economics, 4(1):49-84. 
Stinebrickner, T. R. and Stinebrickner, R. (2011). Math or science? using longitudinal expectations data to examine the process of choosing a college major. NBER WP w16869.

Symonds, W. C., Schwartz, R., and Ferguson, R. F. (2011). Pathways to prosperity: Meeting the challenge of preparing young americans. Cambridge, MA: Pathways to Prosperity Project at Harvard Graduate School of Education.

U.S. Department of Education (2014). National assessment of career and technical education: Final report to congress. Technical report, Washington, DC.

Zietz, J. and Joshi, P. (2005). Academic choice behavior of high school students: economic rationale and empirical evidence. Economics of Education Review, 24(3):297-308.

Zimmermann, K. F., Biavaschi, C., Eichhorst, W., Giulietti, C., Kendzia, M. J., Muravyev, A., Pieters, J., Rodríguez-Planas, N., and Schmidl, R. (2013). Youth unemployment and vocational training. Citeseer. 


\section{Figures and Tables}

Figure 1: Course-taking by American high school students.

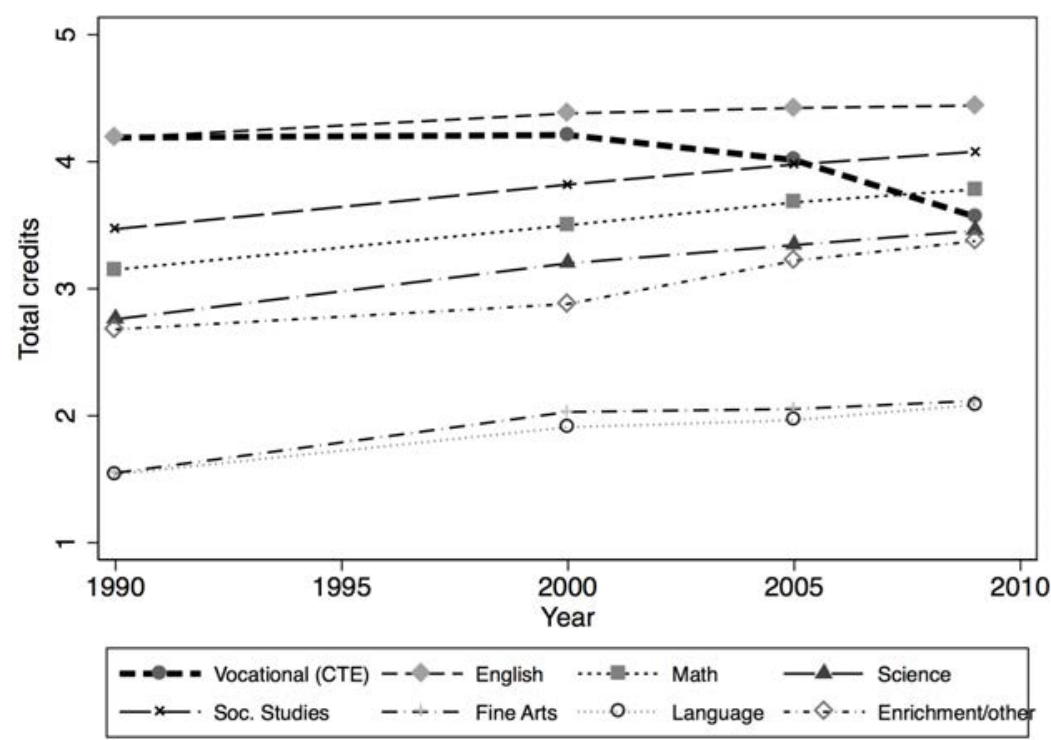

Source: Statistics taken by NCES from High School Transcript Study (HSTS), 1990, 2000, 2005, and 2009. Original table available at http://nces.ed.gov/surveys/ctes/tables/h125.asp. One credit is equal to a daily year-long course. 
Figure 2: CDF of Vocational course-taking.

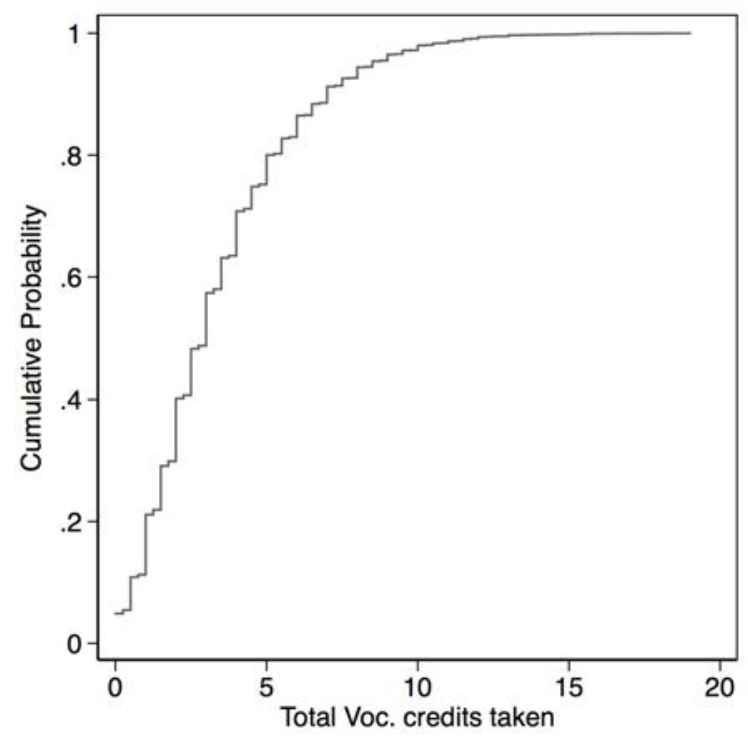

Notes: Figures show cumulative distributions of total and share (Voc/Total) courses taken. One credit is equal to one hour per day for a full academic year. $\mathrm{N}=4,414$. 
Figure 3: Credits taken in each subject.

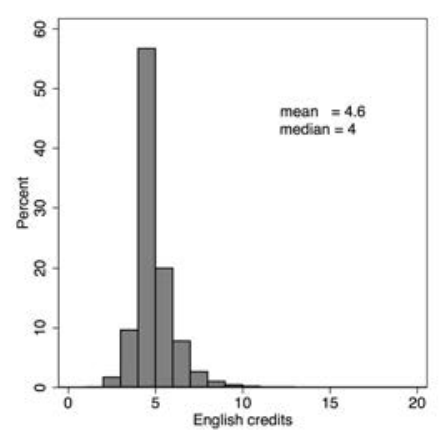

(a) English

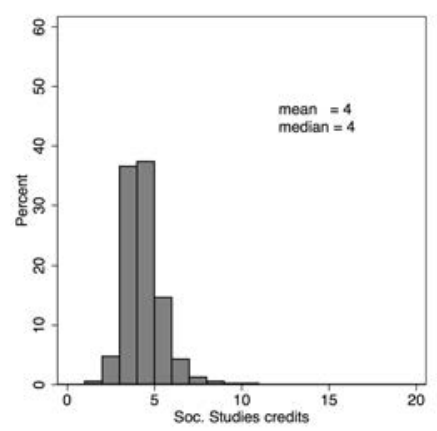

(d) Social studies

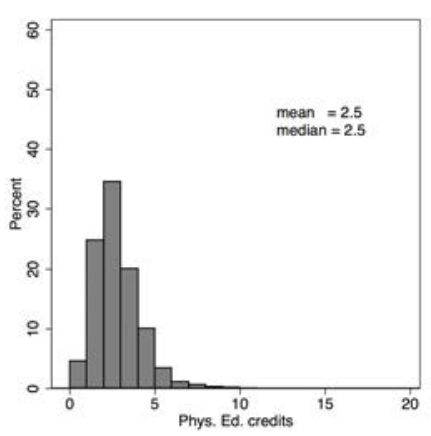

(g) Phys. Ed.

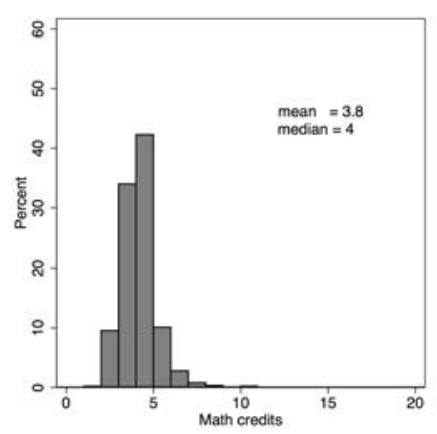

(b) Math

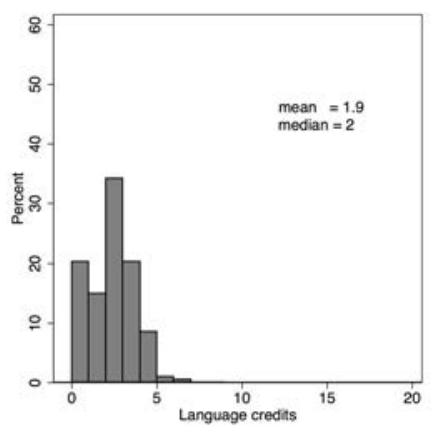

(e) Language

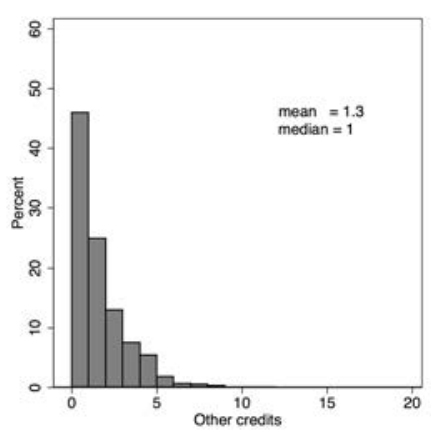

(h) Other

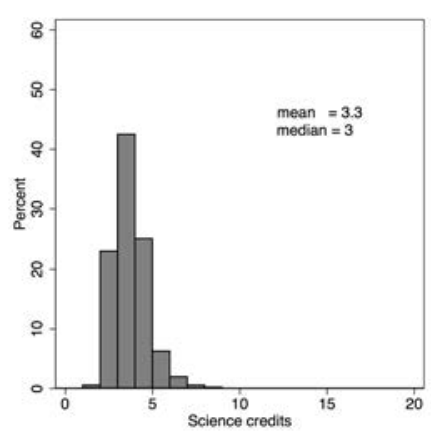

(c) Science

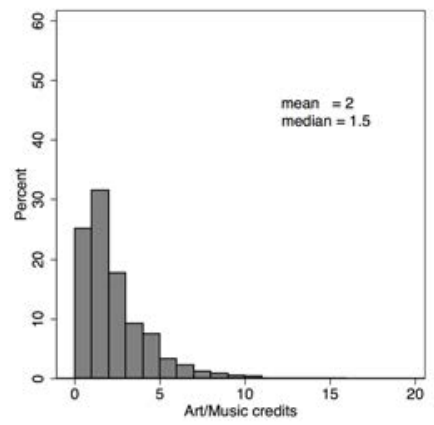

(f) Art/Music

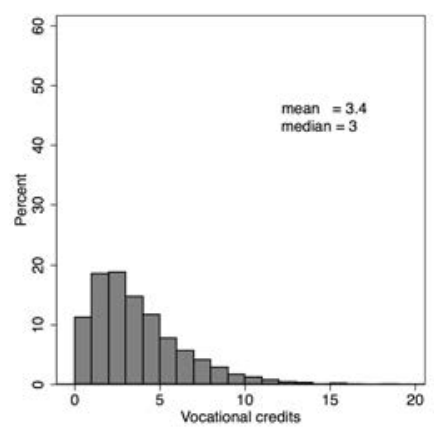

(i) Vocational

Notes: Figures show histograms of credits taken, defined as courses completed, even if it is an F or course that does not accumulate credit hours. One credit is equal to one hour per day for a full academic year. $\mathrm{N}=4,414$. 
Figure 4: Number of Carnegie credits by low/high-experience, by field.

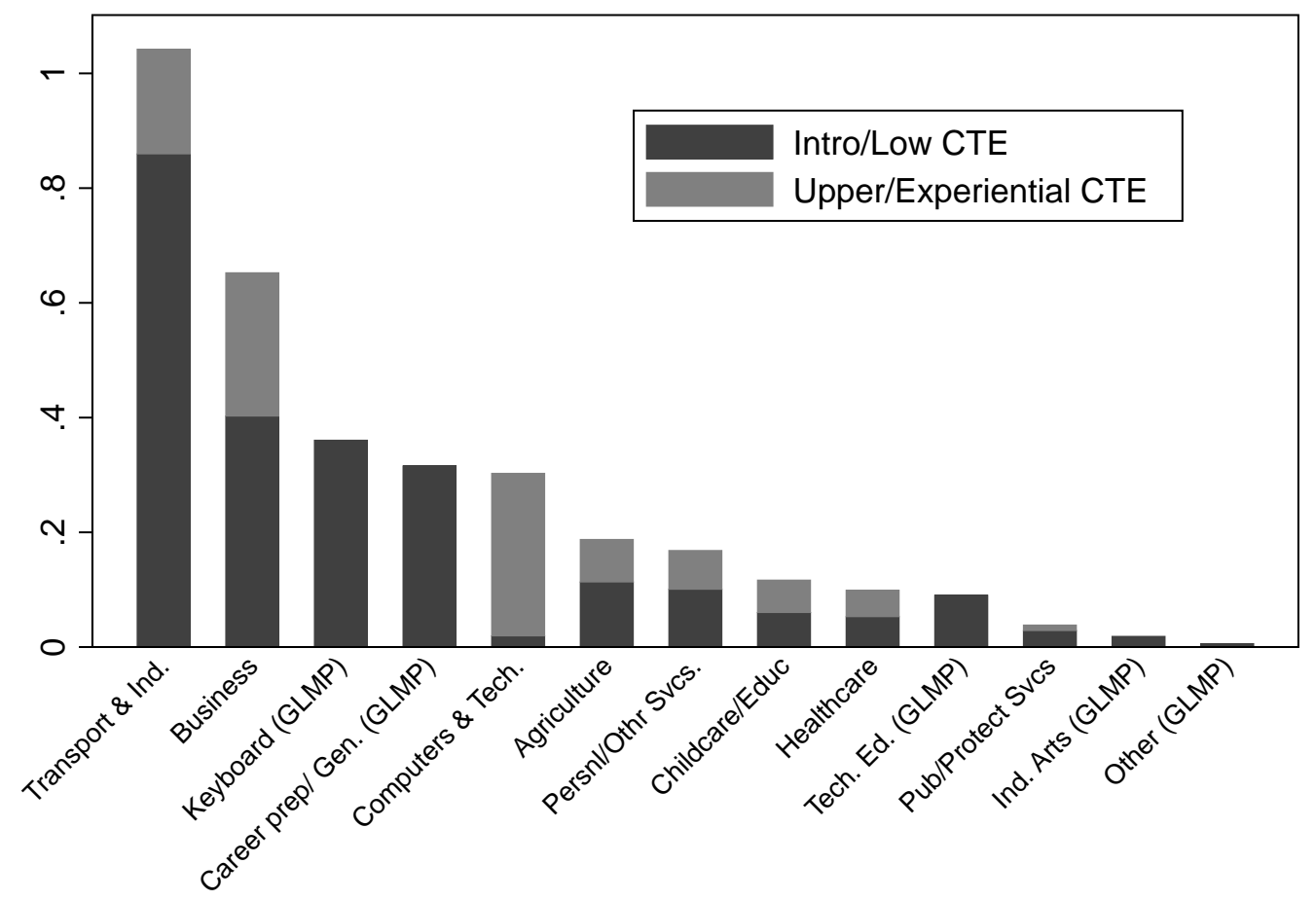

Notes: Figure shows number of carnegie credits earned in each type of vocational course. "Low" courses are entry level. "High/experience" are upper-level or internship/work-based experience courses. One credit is equal to one hour per day for a full academic year. $N=4,414$. 
Figure 5: Number of credits taken by subject and grade.

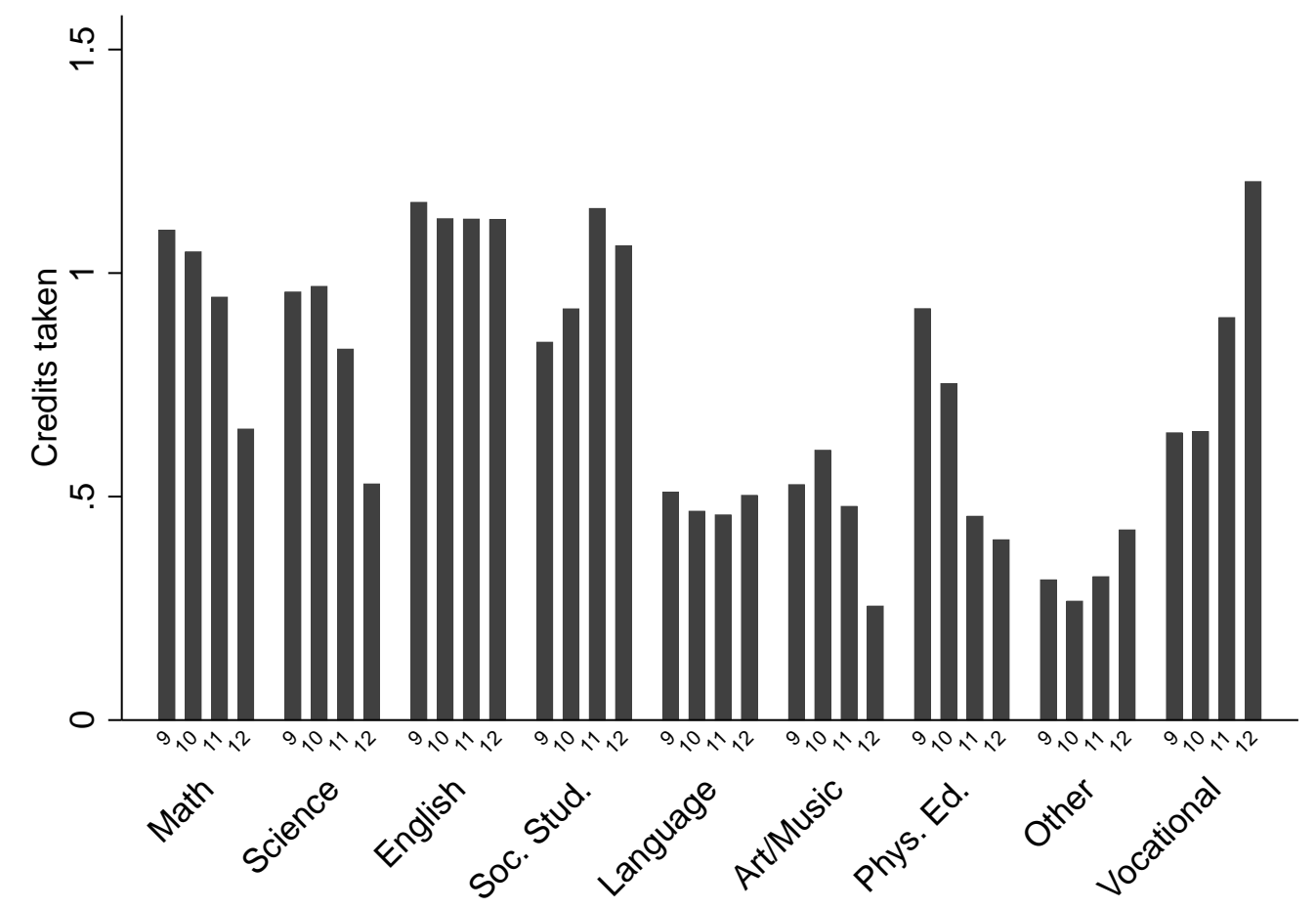

Notes: Students who dropout are only counted above in grades they attempted. One credit is equal to one hour per day for a full academic year. $\mathrm{N}=4,414$. 
Figure 6: Number of credits taken by subject and AFQT quartile.

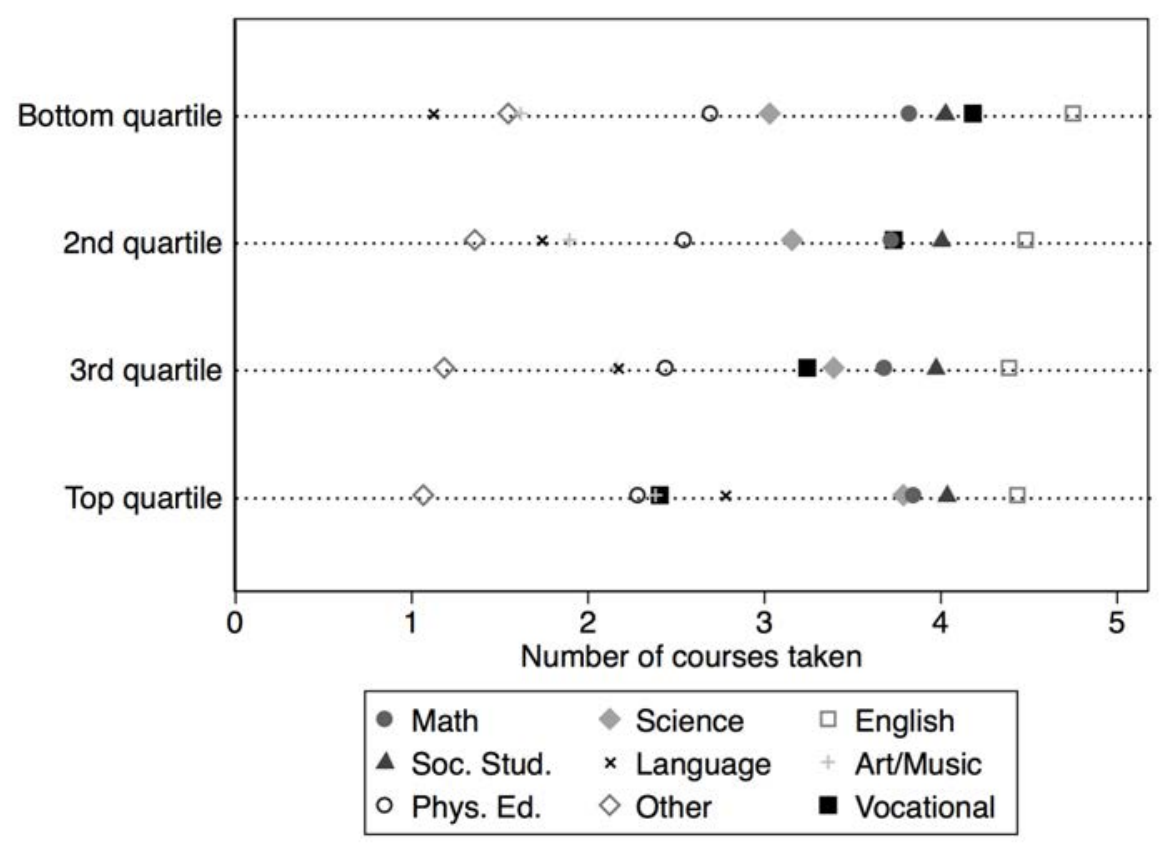

Notes: Shapes mark average total number of credits taken in each subject, by AFQT quartile. One credit is equal to one hour per day for a full academic year. $\mathrm{N}=3,703$ with non-missing AFQT. 
Figure 7: Pairwise joint distributions of Core, Elective and Vocational credits accumulated for high school graduates.
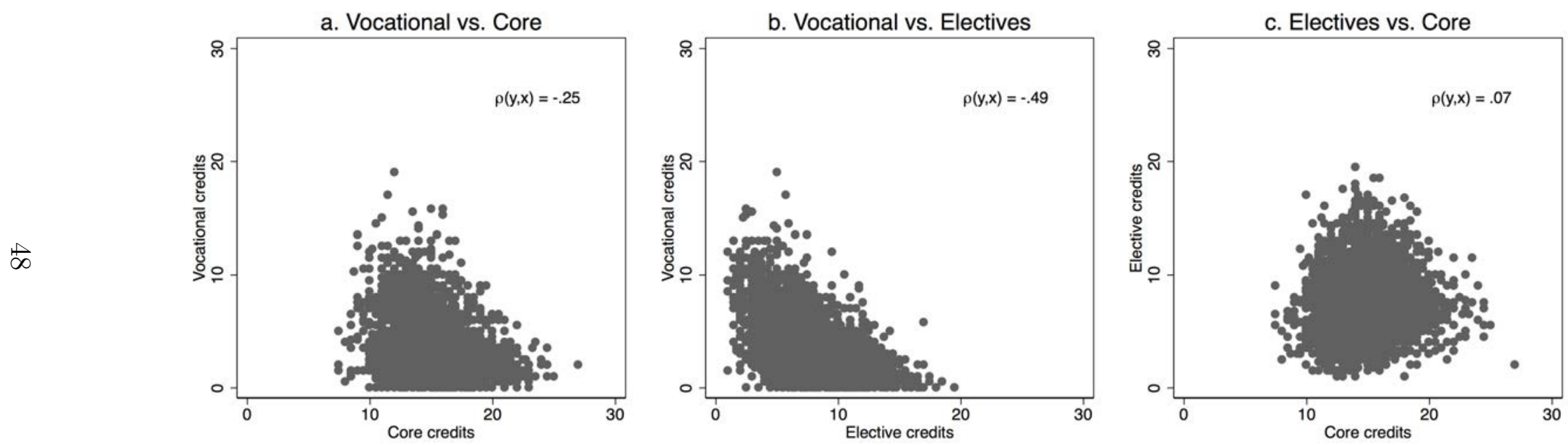

Notes: Figures show scatterplots of total credits accumulated for high school graduates. Core courses include English, math, science and social studies. Electives include art/music, foreign languages, physical education and "other" courses. One credit is equal to a one hour per day full year course. $\mathrm{N}=4,414$. 
Figure 8: Relationship between number of different vocational fields and total low vocational courses.

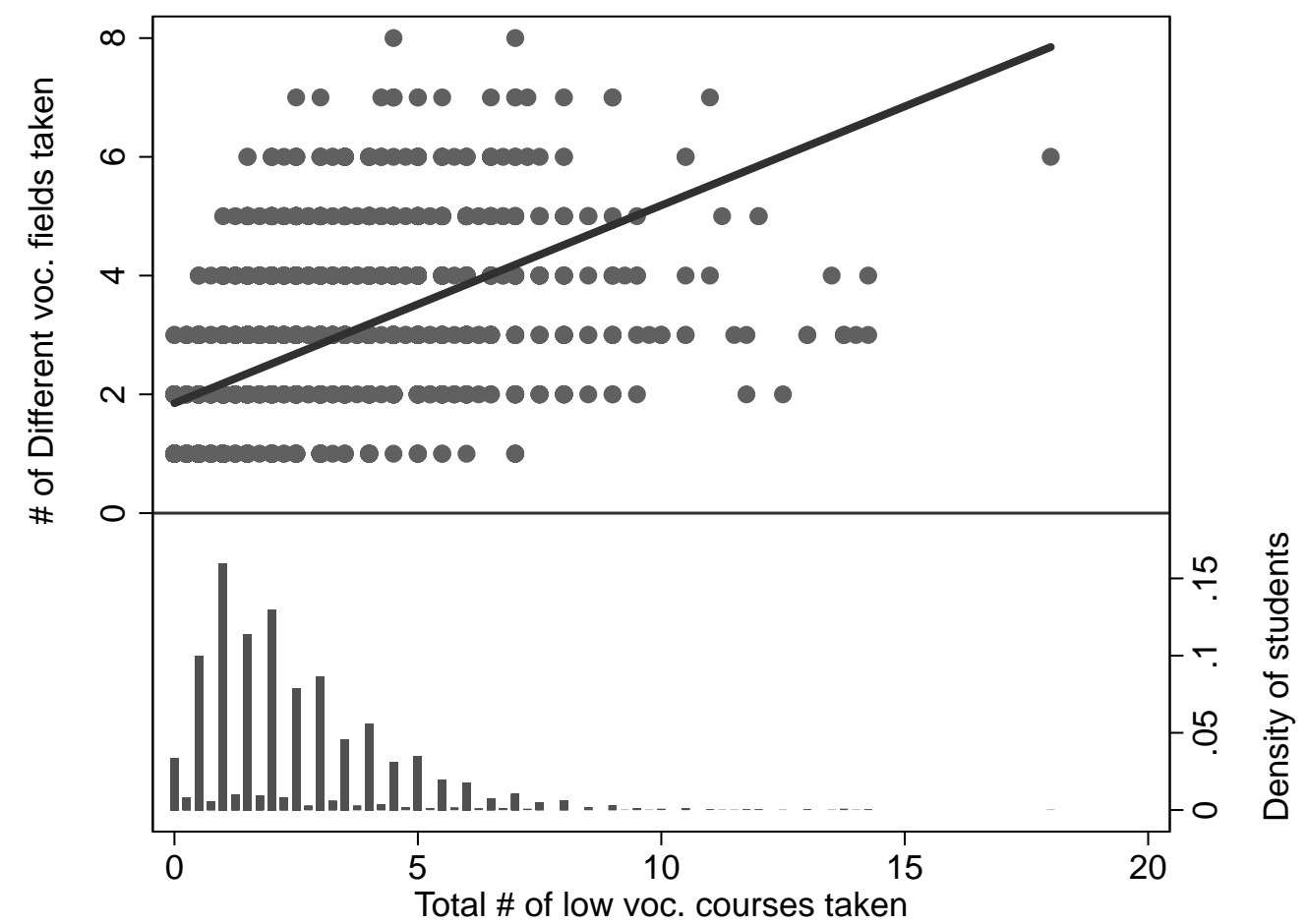

Notes: Sample are all respondents who ever took a vocational course. Upper y-axis indicates the number of different fields in which each respondent took a low level vocational by the total number of low level courses she took (x-axis). The second (lower) y-axis indicates the share of respondents taking each amount of low level vocational courses. Line is a linear fit. 
Table 1: Sample comparison.

\begin{tabular}{|c|c|c|c|c|c|c|}
\hline & \multicolumn{2}{|c|}{ Full NLSY } & \multicolumn{2}{|c|}{ Analysis sample } & \multicolumn{2}{|c|}{ Wage sample } \\
\hline & mean & $(\mathrm{sd})$ & mean & $(\mathrm{sd})$ & mean & $(\mathrm{sd})$ \\
\hline \multicolumn{7}{|l|}{ Demographics } \\
\hline Male & 0.51 & $(0.50)$ & 0.48 & $(0.50)$ & 0.49 & $(0.50)$ \\
\hline Black & 0.26 & $(0.44)$ & 0.22 & $(0.42)$ & 0.23 & $(0.42)$ \\
\hline Hisp. & 0.21 & $(0.41)$ & 0.17 & $(0.37)$ & 0.17 & $(0.38)$ \\
\hline Other race & 0.04 & $(0.19)$ & 0.04 & $(0.20)$ & 0.04 & $(0.19)$ \\
\hline Mom $<\mathrm{HS}^{\dagger}$ & 0.39 & $(0.49)$ & 0.36 & $(0.48)$ & 0.36 & $(0.48)$ \\
\hline Mom $>\mathrm{HS}^{\dagger}$ & 0.14 & $(0.35)$ & 0.17 & $(0.38)$ & 0.17 & $(0.37)$ \\
\hline Ever aid $^{\dagger}$ & 0.44 & $(0.50)$ & 0.37 & $(0.48)$ & 0.39 & $(0.49)$ \\
\hline South, age $12^{\dagger}$ & 0.32 & $(0.47)$ & 0.31 & $(0.46)$ & 0.32 & $(0.47)$ \\
\hline Pov. ratio ${ }^{\dagger}$ & 2.83 & $(2.70)$ & 3.36 & $(2.89)$ & 3.23 & $(2.75)$ \\
\hline Bilingual $^{\dagger}$ & 0.02 & $(0.15)$ & 0.03 & $(0.17)$ & 0.03 & $(0.17)$ \\
\hline Public HS & 0.89 & $(0.32)$ & 0.92 & $(0.28)$ & 0.92 & $(0.27)$ \\
\hline AFQT (Z) & 0.00 & $(1.00)$ & 0.00 & $(1.00)$ & -0.04 & $(1.01)$ \\
\hline AFQT missing & 0.21 & $(0.41)$ & 0.16 & $(0.37)$ & 0.16 & $(0.37)$ \\
\hline \multicolumn{7}{|l|}{ Coursetaking } \\
\hline Voc. low & 2.43 & $(2.24)$ & 2.34 & $(1.96)$ & 2.38 & $(1.95)$ \\
\hline Voc. high & 0.99 & $(1.42)$ & 0.95 & $(1.32)$ & 0.96 & $(1.34)$ \\
\hline Core low & 9.75 & $(2.73)$ & 9.88 & $(2.65)$ & 9.94 & $(2.62)$ \\
\hline Core high & 4.71 & $(3.19)$ & 4.87 & $(3.20)$ & 4.73 & $(3.13)$ \\
\hline Electives & 7.44 & $(2.81)$ & 7.50 & $(2.69)$ & 7.44 & $(2.70)$ \\
\hline Any Voc. & 0.95 & $(0.22)$ & 0.95 & $(0.22)$ & 0.96 & $(0.19)$ \\
\hline \multicolumn{7}{|l|}{ Attainment } \\
\hline$<\mathrm{HS}$ & 0.13 & $(0.33)$ & 0.03 & $(0.17)$ & 0.02 & $(0.15)$ \\
\hline HS & 0.26 & $(0.44)$ & 0.19 & $(0.39)$ & 0.21 & $(0.41)$ \\
\hline Some college & 0.31 & $(0.46)$ & 0.35 & $(0.48)$ & 0.34 & $(0.47)$ \\
\hline 2-year degree & 0.07 & $(0.25)$ & 0.08 & $(0.28)$ & 0.08 & $(0.27)$ \\
\hline 4-year degree & 0.24 & $(0.43)$ & 0.35 & $(0.48)$ & 0.34 & $(0.47)$ \\
\hline Obs. & \multicolumn{2}{|c|}{8,984} & \multicolumn{2}{|c|}{4,414} & \multicolumn{2}{|c|}{3,708} \\
\hline
\end{tabular}

Notes: Analysis sample restricts to respondents with transcripts in all years they attended HS and who attended at least 9th grade. Course-taking restrictions are: took at least 2 of each core course for hs grads; took 1 of each core course if 10th grade + dropout; took between 20 and 36 credits for grads; took at least 4 credits for dropouts. Wage sample consists of respondents who have a reported wage $>\$ 2.00 / h r$ after labor market entry which is defined as the first interview after four consecutive non-enrolled semesters. Ever aid indicates if respondent's family ever received government aid. Public HS indicates if primary high school was public. Gifted indicates if responident ever took a "gifted" class. Core credits include Eng., Math, Science, Social Studies. Electives include Language, Art/Music, Phys. Ed. and Other. Low/High core indicates upper or lower level course within subject-grade. Low vocational indicates entry level course. High vocational indicates second course or higher, or an internship/experiential learning.

${ }^{\dagger}$ Respondents with missing values were recoded to 0 and an indicator equal to 1 is included in regression models indicating those with missing values. 
Table 2: Vocational courses taken, grades 10-12.

\begin{tabular}{|c|c|c|c|c|c|c|c|}
\hline & (1) & $(2)$ & $\begin{array}{c}(3) \\
\text { All voc. cours }\end{array}$ & (4) & (5) & $\begin{array}{c}(6) \\
\text { Voc. low }\end{array}$ & $\begin{array}{c}(7) \\
\text { Voc. high }\end{array}$ \\
\hline Male & $\begin{array}{c}0.598 * * * \\
(0.065)\end{array}$ & $\begin{array}{c}0.596^{* * *} \\
(0.064)\end{array}$ & $\begin{array}{c}0.558^{* * *} \\
(0.065)\end{array}$ & $\begin{array}{c}0.570^{* * *} \\
(0.066)\end{array}$ & $\begin{array}{c}0.555^{* * *} \\
(0.067)\end{array}$ & $\begin{array}{c}0.333^{* * *} \\
(0.051)\end{array}$ & $\begin{array}{c}0.264^{* * * *} \\
(0.038)\end{array}$ \\
\hline Black & $\begin{array}{c}-0.181^{*} \\
(0.093)\end{array}$ & $\begin{array}{c}-0.388^{* * *} \\
(0.095)\end{array}$ & $\begin{array}{c}-0.422^{* * *} \\
(0.096)\end{array}$ & $\begin{array}{c}-0.423^{* * *} \\
(0.099)\end{array}$ & $\begin{array}{c}-0.208^{* *} \\
(0.105)\end{array}$ & $\begin{array}{c}-0.158^{*} \\
(0.081)\end{array}$ & $\begin{array}{l}-0.004 \\
(0.061)\end{array}$ \\
\hline Hisp. & $\begin{array}{c}-0.434^{* * *} \\
(0.095)\end{array}$ & $\begin{array}{c}-0.573^{* * *} \\
(0.098)\end{array}$ & $\begin{array}{c}-0.586^{* * *} \\
(0.098)\end{array}$ & $\begin{array}{c}-0.577^{* * *} \\
(0.102)\end{array}$ & $\begin{array}{c}-0.398 * * * \\
(0.116)\end{array}$ & $\begin{array}{c}-0.265^{* * *} \\
(0.090)\end{array}$ & $\begin{array}{l}-0.105^{*} \\
(0.062)\end{array}$ \\
\hline Other & $\begin{array}{c}-0.690 * * * \\
(0.123)\end{array}$ & $\begin{array}{c}-0.734^{* * *} \\
(0.124)\end{array}$ & $\begin{array}{c}-0.719 * * * \\
(0.125)\end{array}$ & $\begin{array}{c}-0.712^{* * *} \\
(0.129)\end{array}$ & $\begin{array}{c}-0.476 * * * \\
(0.138)\end{array}$ & $\begin{array}{c}-0.230^{* *} \\
(0.106)\end{array}$ & $\begin{array}{c}-0.246^{* * *} \\
(0.071)\end{array}$ \\
\hline Mom $<\mathrm{HS}$ & $\begin{array}{c}0.112 \\
(0.083)\end{array}$ & $\begin{array}{c}0.092 \\
(0.082)\end{array}$ & $\begin{array}{c}0.089 \\
(0.082)\end{array}$ & $\begin{array}{c}0.080 \\
(0.085)\end{array}$ & $\begin{array}{c}0.075 \\
(0.087)\end{array}$ & $\begin{array}{c}0.029 \\
(0.067)\end{array}$ & $\begin{array}{c}0.042 \\
(0.048)\end{array}$ \\
\hline Mom $>$ HS & $\begin{array}{c}-0.454^{* * *} \\
(0.085)\end{array}$ & $\begin{array}{c}-0.395 * * * \\
(0.084)\end{array}$ & $\begin{array}{c}-0.393^{* * *} \\
(0.083)\end{array}$ & $\begin{array}{c}-0.414^{* * *} \\
(0.085)\end{array}$ & $\begin{array}{c}-0.381^{* * *} \\
(0.088)\end{array}$ & $\begin{array}{c}-0.252^{* * *} \\
(0.066)\end{array}$ & $\begin{array}{c}-0.123^{* *} \\
(0.049)\end{array}$ \\
\hline Ever aid & $\begin{array}{c}0.341^{* * *} \\
(0.078)\end{array}$ & $\begin{array}{c}0.270^{* * *} \\
(0.078)\end{array}$ & $\begin{array}{c}0.248^{* * *} \\
(0.078)\end{array}$ & $\begin{array}{c}0.310^{* * * *} \\
(0.081)\end{array}$ & $\begin{array}{c}0.234^{* * *} \\
(0.082)\end{array}$ & $\begin{array}{c}0.204^{* * *} \\
(0.063)\end{array}$ & $\begin{array}{c}0.013 \\
(0.046)\end{array}$ \\
\hline South, age 12 & $\begin{array}{c}0.342^{* * *} \\
(0.078)\end{array}$ & $\begin{array}{c}0.310^{* * *} \\
(0.077)\end{array}$ & $\begin{array}{c}0.328^{* * *} \\
(0.078)\end{array}$ & $\begin{array}{c}0.367^{* * * *} \\
(0.080)\end{array}$ & $\begin{array}{c}0.037 \\
(0.156)\end{array}$ & $\begin{array}{c}0.073 \\
(0.121)\end{array}$ & $\begin{array}{l}-0.058 \\
(0.082)\end{array}$ \\
\hline Rural, age 12 & $\begin{array}{c}0.283^{* * *} \\
(0.109)\end{array}$ & $\begin{array}{c}0.263^{* *} \\
(0.108)\end{array}$ & $\begin{array}{c}0.257^{* *} \\
(0.108)\end{array}$ & $\begin{array}{c}0.230^{* *} \\
(0.110)\end{array}$ & $\begin{array}{c}0.303^{* *} \\
(0.125)\end{array}$ & $\begin{array}{c}0.275^{* * *} \\
(0.095)\end{array}$ & $\begin{array}{c}0.066 \\
(0.068)\end{array}$ \\
\hline Poverty ratio & $\begin{array}{c}-0.001^{* * *} \\
(0.000)\end{array}$ & $\begin{array}{c}-0.000 * * * \\
(0.000)\end{array}$ & $\begin{array}{c}-0.000^{* * *} \\
(0.000)\end{array}$ & $\begin{array}{c}-0.001^{* * *} \\
(0.000)\end{array}$ & $\begin{array}{c}-0.000^{* * *} \\
(0.000)\end{array}$ & $\begin{array}{c}-0.000^{* * *} \\
(0.000)\end{array}$ & $\begin{array}{l}-0.000 \\
(0.000)\end{array}$ \\
\hline Main HS Public & $\begin{array}{c}1.120^{* * *} \\
(0.086)\end{array}$ & $\begin{array}{c}1.072^{* * *} \\
(0.086)\end{array}$ & $\begin{array}{c}1.064^{* * *} \\
(0.086)\end{array}$ & $\begin{array}{c}1.087^{* * *} \\
(0.087)\end{array}$ & $\begin{array}{c}1.100^{* * *} \\
(0.096)\end{array}$ & $\begin{array}{c}0.734^{* * *} \\
(0.072)\end{array}$ & $\begin{array}{c}0.315^{* * *} \\
(0.053)\end{array}$ \\
\hline Gifted & $\begin{array}{c}-0.765^{* * *} \\
(0.070)\end{array}$ & $\begin{array}{c}-0.518^{* * *} \\
(0.073)\end{array}$ & $\begin{array}{c}-0.395^{* * *} \\
(0.081)\end{array}$ & $\begin{array}{c}-0.403^{* * *} \\
(0.082)\end{array}$ & $\begin{array}{c}-0.423^{* * *} \\
(0.086)\end{array}$ & $\begin{array}{c}-0.302^{* * *} \\
(0.063)\end{array}$ & $\begin{array}{c}-0.110^{* *} \\
(0.049)\end{array}$ \\
\hline Bilingual & $\begin{array}{l}-0.049 \\
(0.176)\end{array}$ & $\begin{array}{l}-0.095 \\
(0.172)\end{array}$ & $\begin{array}{l}-0.079 \\
(0.172)\end{array}$ & $\begin{array}{l}-0.090 \\
(0.177)\end{array}$ & $\begin{array}{l}-0.032 \\
(0.188)\end{array}$ & $\begin{array}{c}0.199 \\
(0.154)\end{array}$ & $\begin{array}{c}-0.242^{* * *} \\
(0.076)\end{array}$ \\
\hline AFQT-Z & & $\begin{array}{c}-0.387^{* * *} \\
(0.042)\end{array}$ & $\begin{array}{c}-0.332^{* * *} \\
(0.045)\end{array}$ & $\begin{array}{c}-0.354^{* * *} \\
(0.046)\end{array}$ & $\begin{array}{c}-0.365^{* * *} \\
(0.047)\end{array}$ & $\begin{array}{c}-0.254^{* * *} \\
(0.037)\end{array}$ & $\begin{array}{c}-0.082^{* * *} \\
(0.027)\end{array}$ \\
\hline Core GPA 9th & & & $\begin{array}{c}-0.135^{* * *} \\
(0.038)\end{array}$ & $\begin{array}{c}-0.149^{* * *} \\
(0.039)\end{array}$ & $\begin{array}{c}-0.167^{* * *} \\
(0.040)\end{array}$ & $\begin{array}{c}-0.141^{* * *} \\
(0.032)\end{array}$ & $\begin{array}{l}-0.007 \\
(0.022)\end{array}$ \\
\hline Math 9th, hi & & & $\begin{array}{l}-0.086 \\
(0.116)\end{array}$ & $\begin{array}{l}-0.078 \\
(0.118)\end{array}$ & $\begin{array}{l}-0.060 \\
(0.120)\end{array}$ & $\begin{array}{l}-0.097 \\
(0.091)\end{array}$ & $\begin{array}{c}0.025 \\
(0.072)\end{array}$ \\
\hline Eng 9th, hi & & & $\begin{array}{c}-0.171^{*} \\
(0.087)\end{array}$ & $\begin{array}{c}-0.204^{* *} \\
(0.089)\end{array}$ & $\begin{array}{c}-0.155^{*} \\
(0.092)\end{array}$ & $\begin{array}{c}-0.168^{* *} \\
(0.066)\end{array}$ & $\begin{array}{c}0.021 \\
(0.052)\end{array}$ \\
\hline $\begin{array}{l}\text { State-Cohort FE } \\
\text { H.S. grads only } \\
\text { Year 9th }\end{array}$ & $\checkmark$ & $\checkmark$ & $\checkmark$ & $\begin{array}{l}\checkmark \\
\checkmark\end{array}$ & $\begin{array}{l}\checkmark \\
\checkmark\end{array}$ & $\begin{array}{l}\checkmark \\
\checkmark\end{array}$ & $\begin{array}{l}\checkmark \\
\checkmark\end{array}$ \\
\hline $\begin{array}{l}\mathrm{R}^{2} \\
\text { Obs. (n) }\end{array}$ & $\begin{array}{l}0.105 \\
4,414\end{array}$ & $\begin{array}{l}0.122 \\
4,414\end{array}$ & $\begin{array}{l}0.126 \\
4,414\end{array}$ & $\begin{array}{l}0.140 \\
4,165\end{array}$ & $\begin{array}{l}0.231 \\
4,165\end{array}$ & $\begin{array}{l}0.215 \\
4,165\end{array}$ & $\begin{array}{l}0.131 \\
4,165\end{array}$ \\
\hline
\end{tabular}

Notes: One course (dep. var) is one full year. Math/Eng. high are indicators $=1$ if respondent was in upper level Eng./Math courses in 9th grade. Cols 4-6 are restricted to HS grads only. Core credits include Eng., Math, Science, Social Studies. Electives include Language, Art/Music, Phys. Ed. and Other. Low/High core indicates upper or lower level course within subject-grade. Low vocational indicates entry level course. High vocational indicates second course or higher, or an internship/experiential learning.

Robust standard errors in parentheses.

$(* p<0.10, * * p<0.05, * * * p<0.01$. $)$ 
Table 3: Dep. vars. indicate 2 or 4 year college attendance or completion - conditional on completing high school.

A. Number of credits

\begin{tabular}{|c|c|c|c|c|c|c|}
\hline & $\begin{array}{c}\text { (1) } \\
\text { Attend 2yr }\end{array}$ & $\begin{array}{c}(2) \\
\text { Attend 4yr }\end{array}$ & $\begin{array}{c}(3) \\
\text { Attend any }\end{array}$ & $\begin{array}{c}(4) \\
\text { Earn } 2 y r\end{array}$ & $\begin{array}{c}(5) \\
\text { Earn } 4 \mathrm{yr}\end{array}$ & $\begin{array}{c}(6) \\
\text { Earn any }\end{array}$ \\
\hline Voc. credits, low & $\begin{array}{l}-0.001 \\
(0.004)\end{array}$ & $\begin{array}{l}-0.003 \\
(0.004)\end{array}$ & $\begin{array}{l}-0.004 \\
(0.004)\end{array}$ & $\begin{array}{l}-0.005 \\
(0.008)\end{array}$ & $\begin{array}{c}0.005 \\
(0.007)\end{array}$ & $\begin{array}{c}0.003 \\
(0.005)\end{array}$ \\
\hline Voc. credits, high & $\begin{array}{c}0.009 \\
(0.006)\end{array}$ & $\begin{array}{l}-0.007 \\
(0.006)\end{array}$ & $\begin{array}{c}0.002 \\
(0.005)\end{array}$ & $\begin{array}{l}0.021^{*} \\
(0.011)\end{array}$ & $\begin{array}{l}0.016^{*} \\
(0.009)\end{array}$ & $\begin{array}{c}0.010 \\
(0.007)\end{array}$ \\
\hline Core credits, low & $\begin{array}{c}-0.015^{* * *} \\
(0.004)\end{array}$ & $\begin{array}{c}0.034^{* * *} \\
(0.004)\end{array}$ & $\begin{array}{c}0.019^{* * * *} \\
(0.004)\end{array}$ & $\begin{array}{l}-0.001 \\
(0.009)\end{array}$ & $\begin{array}{c}0.014^{* *} \\
(0.006)\end{array}$ & $\begin{array}{c}0.018^{* * *} \\
(0.005)\end{array}$ \\
\hline Core credits, high & $\begin{array}{c}-0.030 * * * \\
(0.003)\end{array}$ & $\begin{array}{c}0.053^{* * *} \\
(0.004)\end{array}$ & $\begin{array}{c}0.024^{* * *} \\
(0.003)\end{array}$ & $\begin{array}{l}0.018^{*} \\
(0.010)\end{array}$ & $\begin{array}{c}0.030^{* * *} \\
(0.006)\end{array}$ & $\begin{array}{c}0.040^{* * *} \\
(0.005)\end{array}$ \\
\hline Elective credits & $\begin{array}{c}-0.007^{* *} \\
(0.003)\end{array}$ & $\begin{array}{c}0.023^{* * *} \\
(0.003)\end{array}$ & $\begin{array}{c}0.017^{* * *} \\
(0.003)\end{array}$ & $\begin{array}{l}-0.001 \\
(0.008)\end{array}$ & $\begin{array}{c}0.017^{* * * *} \\
(0.004)\end{array}$ & $\begin{array}{c}0.016^{* * *} \\
(0.004)\end{array}$ \\
\hline $\mathrm{R}^{2}$ & 0.166 & 0.344 & 0.218 & 0.301 & 0.229 & 0.227 \\
\hline
\end{tabular}

B. Share of credits

\begin{tabular}{|c|c|c|c|c|c|c|}
\hline Share Voc. low ${ }^{*} 100$ & $\begin{array}{c}0.001 \\
(0.001)\end{array}$ & $\begin{array}{c}-0.007^{* * *} \\
(0.001)\end{array}$ & $\begin{array}{c}-0.006^{* * *} \\
(0.001)\end{array}$ & $\begin{array}{l}-0.001 \\
(0.002)\end{array}$ & $\begin{array}{c}-0.003^{*} \\
(0.002)\end{array}$ & $\begin{array}{c}-0.003^{* *} \\
(0.001)\end{array}$ \\
\hline Share Voc. high*100 & $\begin{array}{c}0.004^{* * *} \\
(0.002)\end{array}$ & $\begin{array}{c}-0.008^{* * *} \\
(0.001)\end{array}$ & $\begin{array}{c}-0.004^{* * *} \\
(0.001)\end{array}$ & $\begin{array}{c}0.006^{* *} \\
(0.003)\end{array}$ & $\begin{array}{l}-0.001 \\
(0.003)\end{array}$ & $\begin{array}{l}-0.001 \\
(0.002)\end{array}$ \\
\hline Share Core low ${ }^{*} 100$ & $\begin{array}{c}-0.002^{*} \\
(0.001)\end{array}$ & $\begin{array}{c}0.002^{* *} \\
(0.001)\end{array}$ & $\begin{array}{c}0.000 \\
(0.001)\end{array}$ & $\begin{array}{c}0.000 \\
(0.003)\end{array}$ & $\begin{array}{l}-0.001 \\
(0.002)\end{array}$ & $\begin{array}{c}0.001 \\
(0.002)\end{array}$ \\
\hline Share Core high*100 & $\begin{array}{c}-0.006^{* * *} \\
(0.001)\end{array}$ & $\begin{array}{c}0.008 * * * \\
(0.001)\end{array}$ & $\begin{array}{c}0.002^{* *} \\
(0.001)\end{array}$ & $\begin{array}{c}0.005 \\
(0.003)\end{array}$ & $\begin{array}{c}0.004^{* *} \\
(0.002)\end{array}$ & $\begin{array}{c}0.007^{* * *} \\
(0.002)\end{array}$ \\
\hline Total credits & $\begin{array}{c}-0.013^{* * *} \\
(0.003)\end{array}$ & $\begin{array}{c}0.029^{* * *} \\
(0.003)\end{array}$ & $\begin{array}{c}0.016^{* * *} \\
(0.002)\end{array}$ & $\begin{array}{c}0.002 \\
(0.006)\end{array}$ & $\begin{array}{c}0.018^{* * *} \\
(0.004)\end{array}$ & $\begin{array}{c}0.020^{* * *} \\
(0.003)\end{array}$ \\
\hline $\mathrm{R}^{2}$ & 0.166 & 0.346 & 0.218 & 0.301 & 0.230 & 0.228 \\
\hline
\end{tabular}

Controls and observations for both panels

\begin{tabular}{|c|c|c|c|c|c|c|}
\hline If attended college & & & & $\checkmark$ & $\checkmark$ & $\checkmark$ \\
\hline Controls & $\checkmark$ & $\checkmark$ & $\checkmark$ & $\checkmark$ & $\checkmark$ & $\checkmark$ \\
\hline AFQT & $\checkmark$ & $\checkmark$ & $\checkmark$ & $\checkmark$ & $\checkmark$ & $\checkmark$ \\
\hline State-Cohort FE & $\checkmark$ & $\checkmark$ & $\checkmark$ & $\checkmark$ & $\checkmark$ & $\checkmark$ \\
\hline Obs. (n) & 4,165 & 4,165 & 4,165 & 919 & 2,495 & 3,414 \\
\hline
\end{tabular}

\footnotetext{
Notes: Sample is limited to HS graduates. Core credits include Eng., Math, Science, Social Studies. Electives include Language, Art/Music, Phys. Ed. and Other. Low/High core indicates upper or lower level course within subject-grade. Low vocational indicates entry level course. High vocational indicates second course or higher, or an internship/experiential learning.Controls include: gender, race, mother's education, rural or South at age 12, family poverty ratio in 1997, public primary high school, any gifted courses, any bilingual education, and fixed effects for 9th grade cohort and 12th grade state of residence.

Robust standard errors in parentheses.
}

$(* p<0.10, * * p<0.05, * * * p<0.01$. $)$ 
Table 4: Dependent variable is log (real) hourly wage.

\begin{tabular}{lccccccc}
\hline \hline & $(1)$ & $(2)$ & $(3)$ & $(4)$ & $(5)$ & $(6)$ & $(7)$ \\
\hline Voc. credits, low & $-0.022^{* * *}$ & -0.004 & -0.001 & -0.000 & 0.001 & 0.002 & 0.001 \\
& $(0.003)$ & $(0.003)$ & $(0.003)$ & $(0.003)$ & $(0.003)$ & $(0.003)$ & $(0.003)$ \\
Voc. credits, high & $0.011^{* *}$ & $0.016^{* * *}$ & $0.017^{* * *}$ & $0.017^{* * *}$ & $0.017^{* * *}$ & $0.021^{* * *}$ & $0.018^{* * *}$ \\
& $(0.005)$ & $(0.005)$ & $(0.005)$ & $(0.005)$ & $(0.005)$ & $(0.005)$ & $(0.005)$ \\
Core credits, low & & & & 0.001 & 0.001 & 0.001 & -0.004 \\
& & & & $(0.003)$ & $(0.003)$ & $(0.003)$ & $(0.003)$ \\
Core credits, high & & & & $0.021^{* * *}$ & $0.017^{* * *}$ & $0.020^{* * *}$ & $0.008^{* *}$ \\
& & & & $(0.003)$ & $(0.003)$ & $(0.003)$ & $(0.003)$ \\
Elective credits & & & & 0.001 & -0.000 & 0.001 & -0.004 \\
& & & & $(0.003)$ & $(0.003)$ & $(0.003)$ & $(0.003)$ \\
Degree & & & & & & & $\checkmark$ \\
State-Cohort FE & & $\checkmark$ & $\checkmark$ & & $\checkmark$ & $\checkmark$ & $\checkmark$ \\
AFQT & & & $\checkmark$ & $\checkmark$ & $\checkmark$ & $\checkmark$ \\
Controls & 0.009 & 0.208 & 0.219 & 0.220 & 0.226 & 0.269 & 0.291 \\
\hline R2 & 3,708 & 3,708 & 3,708 & 3,708 & 3,708 & 3,708 & 3,708 \\
Obs. (n) & 19,029 & 19,029 & 19,029 & 19,029 & 19,029 & 19,029 & 19,029 \\
Obs.*Years (N) & & & & & & $\checkmark$ \\
\hline Notes: Sal & & & & & & \\
\end{tabular}

Notes: Sample is wage sample. Wages are in real $\$ 2010$. Wage sample consists of respondents who have a reported wage $>\$ 2.00 / h r$ after labor market entry - defined as the first interview after four consecutive non-enrolled semesters. Controls include: gender, race, mother's education, rural or South at age 12, family poverty ratio in 1997, public primary high school, any gifted courses, any bilingual education, year entered 9th grade, year of wage record and MSA status when wage was recorded. A one-unit change in credits is equal to a one hour, one year course.Core credits include Eng., Math, Science, Social Studies. Electives include Language, Art/Music, Phys. Ed. and Other. Low/High core indicates upper or lower level course within subject-grade. Low vocational indicates entry level course. High vocational indicates second course or higher, or an internship/experiential learning.

Standard errors clustered on individuals in parentheses.

$(* p<0.10, * * p<0.05, * * * p<0.01$. $)$ 
Table 5: Dependent variable is log hourly wage, course-taking defined in shares of total.

\begin{tabular}{lcccccc}
\hline \hline & $(1)$ & $(2)$ & $(3)$ & $(4)$ & $(5)$ & $(6)$ \\
\hline Share Voc. low*100 & $-0.005^{* * *}$ & -0.001 & 0.000 & 0.000 & 0.000 & 0.001 \\
& $(0.001)$ & $(0.001)$ & $(0.001)$ & $(0.001)$ & $(0.001)$ & $(0.001)$ \\
Share Voc. high*100 & $0.003^{*}$ & $0.004^{* * *}$ & $0.005^{* * *}$ & $0.005^{* * *}$ & $0.005^{* * *}$ & $0.006^{* * *}$ \\
& $(0.001)$ & $(0.001)$ & $(0.001)$ & $(0.001)$ & $(0.001)$ & $(0.001)$ \\
Share Core low*100 & $-0.004^{* * *}$ & -0.001 & -0.000 & 0.000 & 0.000 & -0.000 \\
& $(0.001)$ & $(0.001)$ & $(0.001)$ & $(0.001)$ & $(0.001)$ & $(0.001)$ \\
Share Core high*100 & $0.006^{* * *}$ & $0.005^{* * *}$ & $0.004^{* * *}$ & $0.005^{* * *}$ & $0.005^{* * *}$ & $0.003^{* * *}$ \\
& $(0.001)$ & $(0.001)$ & $(0.001)$ & $(0.001)$ & $(0.001)$ & $(0.001)$ \\
Total credits & & & & $0.003^{*}$ & $0.004^{* *}$ & -0.001 \\
& & & & $(0.002)$ & $(0.002)$ & $(0.002)$ \\
\hline Degree & & & & & & $\checkmark$ \\
State-Cohort FE & & & & & $\checkmark$ & $\checkmark$ \\
AFQT & & $\checkmark$ & $\checkmark$ & $\checkmark$ & $\checkmark$ & $\checkmark$ \\
Controls & & & & $\checkmark$ & $\checkmark$ \\
\hline $\mathrm{R}^{2}$ & 3,708 & 3,708 & 3,708 & 3,708 & 3,708 & 3,708 \\
Obs. (n) & 19,029 & 19,029 & 19,029 & 19,029 & 19,029 & 19,029 \\
Obs.*Years (N) & & & & & $\checkmark$ \\
\hline
\end{tabular}

Notes: Shares are the share of total courses taken in each subject group multiplied by 100. Share of courses that are electives is the omitted category. Sample is wage sample. Wages are in real $\$ 2010$. Wage sample consists of respondents who have a reported wage $>\$ 2.00 / h r$ after labor market entry - defined as the first interview after four consecutive non-enrolled semesters. Controls include: gender, race, mother's education, rural or South at age 12, family poverty ratio in 1997, public primary high school, any gifted courses, any bilingual education, year entered 9th grade, year of wage record and MSA status when wage was recorded. A one-unit change in credits is equal to a one hour, one year course.Core credits include Eng., Math, Science, Social Studies. Electives include Language, Art/Music, Phys. Ed. and Other. Low/High core indicates upper or lower level course within subject-grade. Low vocational indicates entry level course. High vocational indicates second course or higher, or an internship/experiential learning.

Standard errors clustered on individuals in parentheses.

$(* p<0.10, * * p<0.05, * * * p<0.01$. $)$ 
Table 6: Dependent variable is idleness (not working for wage and not enrolled).

\begin{tabular}{lcccccc}
\hline \hline & $(1)$ & $(2)$ & $(3)$ & $(4)$ & $(5)$ & $(6)$ \\
\hline Voc. credits, low & 0.001 & -0.002 & -0.002 & -0.002 & $-0.008^{*}$ & 0.001 \\
& $(0.002)$ & $(0.002)$ & $(0.002)$ & $(0.002)$ & $(0.004)$ & $(0.002)$ \\
Voc. credits, high & $-0.005^{*}$ & $-0.005^{* *}$ & $-0.005^{*}$ & -0.004 & $-0.013^{* *}$ & 0.001 \\
& $(0.003)$ & $(0.003)$ & $(0.003)$ & $(0.003)$ & $(0.005)$ & $(0.003)$ \\
Core credits, low & $-0.004^{* * *}$ & $-0.004^{* * *}$ & $-0.004^{* * *}$ & -0.001 & 0.005 & -0.003 \\
& $(0.002)$ & $(0.002)$ & $(0.002)$ & $(0.002)$ & $(0.004)$ & $(0.002)$ \\
Core credits, high & $-0.014^{* * *}$ & $-0.011^{* * *}$ & $-0.011^{* * *}$ & $-0.005^{* * *}$ & -0.003 & $-0.006^{* * *}$ \\
& $(0.001)$ & $(0.002)$ & $(0.002)$ & $(0.002)$ & $(0.005)$ & $(0.002)$ \\
Elective credits & $-0.007^{* * *}$ & $-0.004^{* * *}$ & $-0.005^{* * *}$ & -0.002 & $-0.010^{* *}$ & -0.001 \\
& $(0.001)$ & $(0.001)$ & $(0.001)$ & $(0.001)$ & $(0.004)$ & $(0.001)$ \\
\hline Attended college & & & & & No & Yes \\
Degree & & & & $\checkmark$ & $\checkmark$ & $\checkmark$ \\
State-Cohort FE & & & $\checkmark$ & $\checkmark$ & $\checkmark$ & $\checkmark$ \\
Controls & & $\checkmark$ & $\checkmark$ & $\checkmark$ & $\checkmark$ & $\checkmark$ \\
AFQT & & & & $\checkmark$ & $\checkmark$ \\
\hline $\mathrm{R}^{2}$ & 4.015 & 0.036 & 0.057 & 0.072 & 0.121 & 0.061 \\
Obs. (n) & 4,414 & 4,414 & 4,414 & 4,414 & 961 & 3,453 \\
Obs. Year (N) & 44,774 & 44,774 & 44,774 & 44,774 & 9,819 & 34,955 \\
\hline
\end{tabular}

Notes: Sample is analysis sample, ages 19 and older. Core credits include Eng., Math, Science, Social Studies. Electives include Language, Art/Music, Phys. Ed. and Other. Low/High core indicates upper or lower level course within subject-grade. Low vocational indicates entry level course. High vocational indicates second course or higher, or an internship/experiential learning.

Standard errors clustered on individuals in parentheses. $(* p<0.10, * * p<0.05, * * * p<0.01$. $)$ 
Table 7: First stage multiple IV regression.

\begin{tabular}{lccc}
\hline \hline & $(1)$ & $(2)$ & $(3)$ \\
& Voc. credits & Core credits & Elective credits \\
\hline Total courses required & $0.155^{* * *}$ & -0.013 & $0.106^{* * *}$ \\
& $(0.027)$ & $(0.019)$ & $(0.024)$ \\
Math courses required & 0.173 & $0.274^{* *}$ & -0.096 \\
& $(0.120)$ & $(0.110)$ & $(0.122)$ \\
Soc. Stud. courses required & $-0.419^{* * *}$ & -0.019 & 0.145 \\
& $(0.110)$ & $(0.112)$ & $(0.111)$ \\
\hline Controls & $\checkmark$ & $\checkmark$ & $\checkmark$ \\
AFQT & $\checkmark$ & $\checkmark$ & $\checkmark$ \\
Highest degree & $\checkmark$ & $\checkmark$ & $\checkmark$ \\
State-Cohort FE & $\checkmark$ & $\checkmark$ & 13.62 \\
\hline Angrist-Pischke F-stat & 26.08 & 6.42 & 2,775 \\
Obs. (n) & 2,775 & 2,775 & 14,207 \\
Obs.*Years (N) & 14,207 & 14,207 & $\checkmark$ \\
\hline
\end{tabular}

Wages are in real $\$ 2010$. Wage sample consists of respondents who have a reported wage $>\$ 2.00 / h r$ after labor market entry - defined as the first interview after four consecutive non-enrolled semesters. Controls include: gender, race, mother's education, rural or South at age 12, family poverty ratio in 1997, public primary high school, any gifted courses, any bilingual education, year entered 9th grade, year of wage record and MSA status when wage was recorded. A one-unit change in credits is equal to a one hour, one year course.

Standard errors clustered on individuals in parentheses. $(* p<0.10, * * p<0.05, * * * p<0.01$. $)$ 
Table 8: Second stage multiple IV regression.

\begin{tabular}{lccc}
\hline \hline & $(1)$ & $(2)$ & $(3)$ \\
& OLS & OLS & IV \\
\hline Voc. credits & $0.007^{* * *}$ & $0.009^{* * *}$ & -0.027 \\
& $(0.003)$ & $(0.003)$ & $(0.031)$ \\
Core credits & 0.001 & 0.002 & 0.062 \\
& $(0.003)$ & $(0.003)$ & $(0.067)$ \\
Elective credits & -0.003 & -0.001 & 0.024 \\
& $(0.003)$ & $(0.003)$ & $(0.043)$ \\
\hline Sample & Full & IV & IV \\
Controls & $\checkmark$ & $\checkmark$ & $\checkmark$ \\
AFQT & $\checkmark$ & $\checkmark$ & $\checkmark$ \\
Highest degree & $\checkmark$ & $\checkmark$ & $\checkmark$ \\
State-Cohort FE & $\checkmark$ & $\checkmark$ & 0.174 \\
\hline $\mathrm{R}^{2}$ & 0.287 & 0.299 & 2,775 \\
obs. (n) & 3,796 & 2,775 & 14,207 \\
Obs. ${ }^{*}$ Years $(\mathrm{N})$ & 19,029 & 14,207 & $\checkmark$ \\
\hline
\end{tabular}

Wages are in real $\$ 2010$. Wage sample consists of respondents who have a reported wage $>\$ 2.00 / h r$ after labor market entry - defined as the first interview after four consecutive non-enrolled semesters. Controls include: gender, race, mother's education, rural or South at age 12, family poverty ratio in 1997, public primary high school, any gifted courses, any bilingual education, year entered 9th grade, year of wage record and MSA status when wage was recorded. A one-unit change in credits is equal to a one hour, one year course.Credits in column 3 are taken from predicted first stage estimates.

Standard errors clustered on individuals in parentheses.

$(* p<0.10, * * p<0.05, * * * p<0.01$. 
Table 9: Dependent variable is log (real) hourly wage.

\begin{tabular}{|c|c|c|c|c|}
\hline & (1) & $(2)$ & Mean earned & Any earned \\
\hline Core credits, low & $\begin{array}{c}0.001 \\
(0.003)\end{array}$ & $\begin{array}{c}-0.004 \\
(0.003)\end{array}$ & 9.9 & 1.00 \\
\hline Core credits, high & $\begin{array}{c}0.020^{* * *} \\
(0.003)\end{array}$ & $\begin{array}{c}0.008^{* * *} \\
(0.003)\end{array}$ & 4.7 & 0.98 \\
\hline Elective credits & $\begin{array}{c}0.001 \\
(0.003)\end{array}$ & $\begin{array}{l}-0.004 \\
(0.003)\end{array}$ & 7.4 & 1.00 \\
\hline Transport \& Industry & $\begin{array}{c}0.014^{* * *} \\
(0.004)\end{array}$ & $\begin{array}{c}0.013^{* * *} \\
(0.004)\end{array}$ & 1.02 & 0.61 \\
\hline Business/Management & $\begin{array}{c}0.015^{* *} \\
(0.006)\end{array}$ & $\begin{array}{l}0.011^{*} \\
(0.006)\end{array}$ & 0.64 & 0.43 \\
\hline GLMP Keyboarding & $\begin{array}{c}0.007 \\
(0.014)\end{array}$ & $\begin{array}{c}0.002 \\
(0.013)\end{array}$ & 0.35 & 0.47 \\
\hline GLMP General & $\begin{array}{l}-0.004 \\
(0.007)\end{array}$ & $\begin{array}{l}-0.004 \\
(0.007)\end{array}$ & 0.30 & 0.24 \\
\hline Computer Tech. & $\begin{array}{c}0.009 \\
(0.010)\end{array}$ & $\begin{array}{c}0.005 \\
(0.010)\end{array}$ & 0.29 & 0.27 \\
\hline Agriculture & $\begin{array}{l}0.017^{*} \\
(0.009)\end{array}$ & $\begin{array}{c}0.015 \\
(0.009)\end{array}$ & 0.19 & 0.10 \\
\hline Service & $\begin{array}{l}-0.000 \\
(0.006)\end{array}$ & $\begin{array}{c}-0.001 \\
(0.006)\end{array}$ & 0.17 & 0.11 \\
\hline Educ. \& Child Care & $\begin{array}{l}-0.006 \\
(0.009)\end{array}$ & $\begin{array}{c}-0.008 \\
(0.009)\end{array}$ & 0.12 & 0.11 \\
\hline GLMP Tech. Ed. & $\begin{array}{l}-0.020 \\
(0.016)\end{array}$ & $\begin{array}{c}-0.016 \\
(0.016)\end{array}$ & 0.09 & 0.10 \\
\hline Health care & $\begin{array}{c}0.022^{* *} \\
(0.010)\end{array}$ & $\begin{array}{c}0.022^{* *} \\
(0.010)\end{array}$ & 0.09 & 0.06 \\
\hline Pub. \& Protect. Svcs. & $\begin{array}{l}-0.018 \\
(0.013)\end{array}$ & $\begin{array}{l}-0.017 \\
(0.012)\end{array}$ & 0.04 & 0.03 \\
\hline GLMP Ind. Arts & $\begin{array}{c}-0.057^{* *} \\
(0.026)\end{array}$ & $\begin{array}{c}-0.051^{* *} \\
(0.025)\end{array}$ & 0.02 & 0.02 \\
\hline GLMP Other & $\begin{array}{c}-0.016 \\
(0.021)\end{array}$ & $\begin{array}{c}-0.012 \\
(0.019)\end{array}$ & 0.01 & 0.01 \\
\hline $\begin{array}{l}\text { Degree } \\
\text { Controls } \\
\text { AFQT } \\
\text { State-Cohort FE }\end{array}$ & $\begin{array}{l}\checkmark \\
\checkmark \\
\checkmark\end{array}$ & $\begin{array}{l}\checkmark \\
\checkmark \\
\checkmark \\
\checkmark\end{array}$ & & \\
\hline $\begin{array}{l}\mathrm{R}^{2} \\
\text { Obs. (n) } \\
\text { Obs. }{ }^{*} \text { Years }(\mathrm{N})\end{array}$ & $\begin{array}{c}0.270 \\
3,708 \\
19,029\end{array}$ & $\begin{array}{c}0.292 \\
3,708 \\
19,029\end{array}$ & & \\
\hline
\end{tabular}

Notes: Wages are in real $\$ 2010$. Wage sample consists of respondents who have a reported wage $>\$ 2.00 / h r$ after labor market entry - defined as the first interview after four consecutive non-enrolled semesters. Controls include: gender, race, mother's education, rural or South at age 12, family poverty ratio in 1997, public primary high school, any gifted courses, any bilingual education, year entered 9th grade, year of wage record and MSA status when wage was recorded. A one-unit change in credits is equal to a one hour, one year course.

Standard errors clustered on individuals in parentheses.

$(* p<0.10, * * p<0.05, * * * p<0.01$. $)$ 
Table 10: Robustness checks. Dependent variable is log wage.

\begin{tabular}{|c|c|c|c|c|c|c|c|c|c|}
\hline & (1) & $(2)$ & $(3)$ & $(4)$ & $(5)$ & (6) & $(7)$ & $(8)$ & (9) \\
\hline Voc. credits, low & $\begin{array}{l}0.001 \\
(0.003)\end{array}$ & $\begin{array}{l}0.001 \\
(0.003)\end{array}$ & $\begin{array}{l}0.002 \\
(0.004)\end{array}$ & $\begin{array}{l}0.001 \\
(0.003)\end{array}$ & $\begin{array}{l}0.003 \\
(0.004)\end{array}$ & $\begin{array}{l}0.003 \\
(0.004)\end{array}$ & $\begin{array}{l}0.011 \\
(0.007)\end{array}$ & & $\begin{array}{l}-0.002 \\
(0.004)\end{array}$ \\
\hline Voc. credits, high & $\begin{array}{l}0.018^{* * *} \\
(0.005)\end{array}$ & $\begin{array}{l}0.020^{* * *} \\
(0.005)\end{array}$ & $\begin{array}{l}0.019^{* * *} \\
(0.005)\end{array}$ & $\begin{array}{l}0.017^{* * *} \\
(0.004)\end{array}$ & $\begin{array}{l}0.019 * * * \\
(0.006)\end{array}$ & $\begin{array}{l}0.020^{* * *} \\
(0.005)\end{array}$ & $\begin{array}{l}0.021^{* *} \\
(0.010)\end{array}$ & & $\begin{array}{l}0.015^{*} \\
(0.007)\end{array}$ \\
\hline Core credits, low & $\begin{array}{l}-0.004 \\
(0.003)\end{array}$ & $\begin{array}{l}-0.003 \\
(0.003)\end{array}$ & $\begin{array}{c}-0.006^{*} \\
(0.003)\end{array}$ & $\begin{array}{l}-0.002 \\
(0.002)\end{array}$ & $\begin{array}{l}-0.005 \\
(0.003)\end{array}$ & $\begin{array}{l}-0.003 \\
(0.003)\end{array}$ & $\begin{array}{l}-0.002 \\
(0.003)\end{array}$ & $\begin{array}{l}-0.004 \\
(0.003)\end{array}$ & $\begin{array}{l}-0.004 \\
(0.003)\end{array}$ \\
\hline Core credits, high & $\begin{array}{l}0.008 * * \\
(0.003)\end{array}$ & $\begin{array}{l}0.007^{* *} \\
(0.003)\end{array}$ & $\begin{array}{l}0.007^{* *} \\
(0.003)\end{array}$ & $\begin{array}{l}0.010^{* * *} \\
(0.002)\end{array}$ & $\begin{array}{l}0.009^{* * *} \\
(0.003)\end{array}$ & $\begin{array}{l}0.009^{* * *} \\
(0.003)\end{array}$ & $\begin{array}{l}0.009^{* * *} \\
(0.004)\end{array}$ & $\begin{array}{l}0.008^{* * *} \\
(0.003)\end{array}$ & $\begin{array}{c}0.008 * * \\
(0.003)\end{array}$ \\
\hline Elective credits & $\begin{array}{l}-0.004 \\
(0.003)\end{array}$ & $\begin{array}{l}-0.002 \\
(0.003)\end{array}$ & $\begin{array}{l}-0.002 \\
(0.003)\end{array}$ & $\begin{array}{l}-0.003 \\
(0.002)\end{array}$ & $\begin{array}{c}-0.005^{*} \\
(0.003)\end{array}$ & $\begin{array}{c}-0.005^{*} \\
(0.003)\end{array}$ & $\begin{array}{l}-0.006^{* *} \\
(0.003)\end{array}$ & $\begin{array}{l}-0.004 \\
(0.002)\end{array}$ & $\begin{array}{l}-0.004 \\
(0.003)\end{array}$ \\
\hline Concentrator & & & & & & & & $\begin{array}{l}0.032^{* *} \\
(0.015)\end{array}$ & $\begin{array}{l}0.027 \\
(0.018)\end{array}$ \\
\hline Specialist & & & & & & & & $\begin{array}{l}0.062^{* * *} \\
(0.018)\end{array}$ & $\begin{array}{l}0.020 \\
(0.029)\end{array}$ \\
\hline Sample limitation & None & None & $\begin{array}{l}\text { Non- } \\
\text { missing } \\
\text { req's }\end{array}$ & $\begin{array}{l}\text { Relax } \\
\text { credit } \\
\text { constraint }\end{array}$ & Age $>23$ & Hours $\geq 35$ & $\begin{array}{l}\text { Voc. } \\
\text { credits } \leq 4\end{array}$ & None & None \\
\hline Requirements & & & $\checkmark$ & & & & & & \\
\hline County-Cohort FE & & $\checkmark$ & & & & & & & \\
\hline State-Cohort FE & $\checkmark$ & & $\checkmark$ & $\checkmark$ & $\checkmark$ & $\checkmark$ & $\checkmark$ & $\checkmark$ & $\checkmark$ \\
\hline Degree & $\checkmark$ & $\checkmark$ & $\checkmark$ & $\checkmark$ & $\checkmark$ & $\checkmark$ & $\checkmark$ & $\checkmark$ & $\checkmark$ \\
\hline Controls & $\checkmark$ & $\checkmark$ & $\checkmark$ & $\checkmark$ & $\checkmark$ & $\checkmark$ & $\checkmark$ & $\checkmark$ & $\checkmark$ \\
\hline AFQT & $\checkmark$ & $\checkmark$ & $\checkmark$ & $\checkmark$ & $\checkmark$ & $\checkmark$ & $\checkmark$ & $\checkmark$ & $\checkmark$ \\
\hline $\mathrm{R}^{2}$ & 0.291 & 0.336 & 0.296 & 0.288 & 0.264 & 0.329 & 0.302 & 0.291 & 0.291 \\
\hline Obs. (n) & 3,708 & 3,708 & 3,285 & 4,338 & 3,575 & 3,403 & 2,660 & 3,708 & 3,708 \\
\hline Obs. *Years (N) & 19029 & 19,029 & 16,935 & 22,674 & 14,827 & 14,536 & 13,170 & 19,029 & 19,029 \\
\hline
\end{tabular}

Notes: Sample is wage sample. Core credits include Eng., Math, Science, Social Studies. Electives include Language, Art/Music, Phys. Ed. and Other. Low/High core indicates upper or lower level course within subject-grade. Low vocational indicates entry level course. High vocational indicates second course or higher, or an internship/experiential learning.

Standard errors clustered on individuals in parentheses.

$(* p<0.10, * * p<0.05, * * * p<0.01$.) 
Table A1: Vocational course types in the NLSY97.

1. Basic Keyboarding/Typewriting (GLMP).

2. Industrial Arts (GLMP).

3. Career Preparation/General Work Experience (GLMP).

4. Technology Education (GLMP).

5. Other (GLMP).

6. Agriculture and Renewable Resources.

7. Business:

Business Services; Marketing and Distribution; Business Management.

8. Health Care.

9. Public and Protective Services.

10. Transportation and Industry:

Construction trades; Material Moving; Mechanics and repair; Precision

Production (Drafting/Graphics/Printing/Metals/Wood/Plastics).

11. Computers and technology:

Computer Technology, Communication Technology; Other technology

12. Service: Personal and Other Services; Food Service and Hospitality

13. Child Care and Education 